\title{
THE NUCLEAR PATTERN AND THE FIBER CONNECTIONS OF CERTAIN NON-CORTICAL AREAS OF THE TELENCEPHALON OF THE MINK (MUSTELA VISON)
}

\author{
MARGUERITE WATSON JESERICH \\ Laboratory of Comparative Neurology, Department of Anatomy, \\ University of Michigan, Ann Arbor ${ }^{1}$ \\ TWELVE PLATES (TWENTY-THREE FIGURES) \\ INTRODUCTION
}

The mink is a semiaquatic mammal with a markedly elongated but proportionately narrowed hemisphere, its telencephalon resembling more closely that of the weasel than that of the cat or the dog. Its telencephalon shows, in general, the morphological pattern characteristic of carnivores but exhibits certain variations and modifications of structure which distinguish it from the homologous regions in the cat and the dog. These differences appear to be in line with differences in the behavior patterns of the forms considered. The fissures typical of the carnivore hemisphere, perhaps especially those of its lateral wall which mark the territory roughly included in the island region of higher forms, are very clear cut. A slight temporal pole is indicated. On the medial brain wall a relatively large corpus callosum is evident (fig. 1 ). The olfactory bulbs, which are attached to a short crus, project (about $1 \mathrm{~mm}$.) in front of the hemispheres. The accessory olfactory bulbs are fairly well marked.

\section{MATERIAL AND METHODS}

For this study of the brain of the mink, two series were available. One of these consisted of transversely cut serial sections of $25 \mu$ thickness, stained with toluidin blue; the other series, also serially cut in a transverse plane at $25 \mu$, was prepared by the Weigert technique. For general orientation, two gross specimens of the brain were available. Photographs of the gross material and photomicrographs of the sections have been used to illustrate this paper. The photomicrographs were prepared by George J. Smith, research technical assistant in the Department of Anatomy of the University of Michigan.

${ }^{2} \mathrm{~A}$ dissertation submitted in partial fulfillment of the requirements for the degree of doctor of philosophy in the University of Michigan. 
The pertinent literature has been considered with the descriptions of the various nuclear masses and fiber systems. No papers dealing with the finer structure of the telencephalon in the mink have come to the attention of the author.

The author wishes to express her sincere gratitude for the privilege of working in the laboratories of the Department of Anatomy of the University of Michigan and also to Dr. Elizabeth Crosby for her assistance in the preparation of this paper.

DESCRIPTION OF NUCLEAR MATERIAL

\section{Olfactory bulb}

Various observers have described the submammalian olfactory bulb, among whom Jansen ('30, cyclostomes), Sheldon ('12, teleosts), Herrick ('33, amphibians) and Crosby and Humphrey ('39, reptiles and birds) may be mentioned. The mammalian olfactory bulb has likewise interested many workers and has been considered in representative mammals from marsupials to man. Its microscopic structure has been described and figured in the marsupials by McCotter ('12), Herrick ('24) and Obenchain ('25), in the edentates by Sonntag and Woollard ('25), in rodents by van Gehuchten and Martin (1891) Gurdjian ('25), Young ('36) and others, in Chiroptera by Humphrey ('36) and in various subprimates and primates, including man, by Humphrey and Crosy ('38) and Crosby and Humphrey ('39).

The mink exhibits the pattern characteristic for the mammalian olfactory formation. As in other marnmals (Ariëns Kappers, Huber and Crosby, '36), the layers of the olfactory bulb (figs. 2, 3, 4, 15) from periphery to ventricle are: the layer of entering olfactory nerve fibers, the glomerular layer, the external plexiform (the external granular and molecular layers), the mitral cell layer, the internal plexiform layer, the internal granular layer and the white substance and the ependymal lining of the olfactory ventricle. In the most rostral area of the olfactory bulb there are large groups of entering olfactory fila forming dorsal and lateral sectors; very few fibers are found on the medial surface but a somewhat larger group is discernible on the ventromedial surface of the bulb. Farther caudalward the dorsal (especially that portion of the dorsal sector beneath the hemisphere) and the dorsolateral sectors become smaller, and a ventromedial group of fila distributing to a sector appears. In still more caudal regions there are ventrolateral, ventral and ventromedial groups of fila and corresponding sectors, the ventromedial being the last to disappear. In the rabbit (Young, '36) 
the entering nerve fibers are most numerous in ventral and rostral portions of the bulb with very few reaching the dorsal surface, and in the cat (Fox, '40) and in the rostral portion, particularly on the medial and lateral walls. In the bat (Humphrey, '36) the layer of entering fila is thickest on the ventral surface of the bulb.

The olfactory fila (figs. 2, 3, 4, 15), as they enter the bulb in the mink, show an interesting arrangement. They fall into several groups and each group appears to enter the middle of a sector (figs. 2, 3,4) of olfactory formation and to supply only that sector. Thus a simple localization pattern for olfactory impulses would appear to have some anatomic basis in this arrangement. This sector pattern corresponds to that described in man by Humphrey and Crosby in 1938 and in the pig and the weasel by Crosby and Humphrey in 1939.

The glomerular layer (figs. 2, 3, 4, 15) is an unbroken, compact zone which forms the complete outer layer of the olfactory formation. The glomerular layer lies just within the entering olfactory fila. It is the region of synapse of the entering fila with the processes of mitral cells and possibly other cells of the olfactory formation. The glomeruli are numerous and of various sizes. In the toluidin blue material they are unstained but are outlined by the periglomerular granules. This layer, which is often more than a single glomerulus thick in its rostral part, is replaced first dorsally by the accessory olfactory bulb, which has its own layers including a glomerular layer. The glomerular layer of the accessory olfactory bulb (figs. 3,15 ), however, receives vomeronasal rather than olfactory fibers. Behind the rostral end of the accessory bulb the glomerular layer is replaced gradually by the anterior olfactory nucleus.

The external granular layer (figs. 2,3,4,15) is composed of : (a) small, round, darkly stained cells, (b) some more lightly stained, larger irregularly shaped cells and (c) a few out-wandering mitral cells. The outer border of the external granular layer is very irregular, outlining and, in some areas, almost encircling the glomeruli. The inner border is quite irregular and outlines the external molecular layer.

Throughout the rostrocaudal extent of the bulb there are thick patches or groups of out-wandering mitral cells within the external molecular layer (figs. $2,3,4,15$ ) which are close to the external granular layer. There are also many scattered out-wandering mitral cells throughout the molecular layer. This layer also contains some very small, lightly stained, round cells.

The mitral cell layer (figs. $2,3,4,15$ ) is made up of one layer of mitral cells and many very small, round, darkly stained neurons. The mitral 
cell layer forms the outline for the inner layers and is distinctly invaginated in certain regions. This invagination is in relation to the sector arrangement of the incoming fila (figs. 2, 3).

Inside the mitral cell layer is a very narrow internal molecular layer (figs. 2, 3,4). This is almost indistinguishable from the internal granular layer.

The internal granular layer (figs. 2, 3,4), inside of which is the white substance, is very wide, extending from the internal molecular layer to fiber tracts surrounding the ependymal gray around the ventricle. Its peculiar concentric lamination, in which the granule cell groups diminish in size as they near the periventricular gray, has been described by Young ('36) in the rabbit, by Humphrey ('36) for the bat and by Fox ('40) for the cat.

The ventricle of the olfactory bulb (fig. 3) is extremely small in the mink, in many sections being indistinguishable except for the ependyma which lines it. This ependyma is surrounded by a band of small cells, many of them supporting elements, some of them neurons and possibly some indifferent cells. This wide band persists after all the other layers of the olfactory formation have been replaced by the anterior olfactory nucleus.

The dorsomedial portion of the olfactory formation is the first to be displaced by the anterior olfactory nucleus, followed almost immediately, in the most dorsal part, by the accessory olfactory bulb (fig. 3). Then the anterior olfactory nucleus successively replaces the olfactory formation in the dorsolateral, lateral, medial and ventral portions, the ventromedial part being the last to disappear (fig. 4).

\section{Accessory olfactory bulb}

The accessory olfactory bulb (figs. 3, 15) lies immediately beneath the hemisphere. It appears as a triangular protuberance (fig. 3 ) at the most dorsal portion of the olfactory bulb, where the olfactory formation has disappeared, and just behind the most rostral extension of the nucleus olfactorius anterior. It disappears at planes in which the olfactory formation is still present on the lateral, medial and ventral surfaces of the bulb. The accessory olfactory bulb, then, is rather small in the mink, much smaller than in the cat (Fox, '40), and somewhat smaller than in the rabbit (Young, '36). It exhibits the superficial, glomerular, external granular and molecular layers of the olfactory formation, as well as being richly supplied with mitral cells. The accessory bulb is not found in the bat (Humphrey, '36) nor in adult man (Crosby and Humphrey, '41) but it does appear in human embryos 
(Humphrey, '40). In the macaque it may be absent or present. If present, it apparently may be represented only on one side (Crosby and Humphrey, '39; Lauer, '45).

\section{Anterior olfactory nucleus}

The anterior olfactory nucleus (figs. $3,4,5,15$ ) has been defined as the secondary, relatively undifferentiated gray between the olfactory formation and the differentiated centers of the hemisphere (Herrick, '24). It appears, then, in planes just rostral to the accessory olfactory bulb, where it replaces, dorsomedially, the cells of the internal plexiform layer of the olfactory formation (fig. 3 ). It extends caudally to planes immediately in front of nucleus accumbens. The various parts of the anterior olfactory nucleus are similar in cell type and their names are determined by their positions and caudal relations. Figures 3 to 5 show the various subdivisions of this nucleus. In figure 4 the anterior olfactory nucleus exhibits its typical configuration. Its outline resembles that of a grain of corn, the tip of which points ventromedialward, medial to the ventral portion of the periventricular gray. One or two cells typical of the nucleus can be seen in the periventricular gray, between and partially joining the lower portions of the nucleus. In some more caudal sections there are a greater number of cells which bridge across between pars posterior of the nucleus and the periventricular gray (fig. 5), showing probably the earlier embryonic relations in this region, as the neurons forming the nucleus migrate away from the central gray. The various portions of the anterior olfactory nucleus have been described in many submammalian and mammalian forms (Herrick, '24, Obenchain, '25, Gurdjian, '25, Sonntag and Woollard, '25; Ariëns Kappers, Huber and Crosby, '36, Young, '36, Humphrey, '36, Crosby and Humphrey, '39, Fox, '40 and others). This nucleus is very poorly developed in primates (Crosby and Humphrey, '41, Lauer, '45).

The dorsal portion of the anterior olfactory nucleus (fig. 3) appears most rostrally, replacing the cells of the internal plexiform layer in the dorsal part of the olfactory bulb. It increases rapidly in size as it is followed caudalward, appearing in transverse sections (fig. 4) as a dorsal arch (15 to 20 cells thick) over the ventricle. From this dorsal portion two pillars extend ventrally, narrowing at their respective bases so that they are only six to ten cells in thickness. The medial pillar (pars medialis of the nucleus) extends farther ventralward than the lateral one (pars lateralis) ; both blend into the periventricular gray. The accessory bulb lies above pars dorsalis of the anterior olfactory nucleus 
(fig. 3), the two being separated from each other by the outer plexiform layer, the mitral cell layer and the inner plexiform layer of the olfactory formation. Pars dorsalis forms the dorsal apex of the anterior olfactory nucleus as it continues caudalward in the crus (fig. 5). As the hemisphere is reached, it is gradually replaced by the neopallial cortex (fig. 5). Pars medialis retains its medial position in the crus and, as this latter joins the hemisphere, passes over dorsally into the anterior continuation of the hippocampus (fig. 5). Its ventral portion (nuc. olf. ant. p. med. vent., fig 4 ) is replaced by septal gray. Pars lateralis lies along the lateral gray of the crus (fig. 4) and becomes continuous with the anterior continuation of the piriform cortex, the so-called prepiriform cortex (fig. 5). Pars ventralis (fig. 5) lies at the lower border of pars lateralis and is connected with pars medialis only by seattered cells. The various parts of nucleus olfactorius anterior form a gray ring around the ventricle in many submammals and mammals. This was first noted in marsupials by Herrick ('24) and Obenchain ('25) and since has been described repeatedly in most subprimate forms by the various students of this region. However, in the mink, the ventral portion of this gray ring is poorly developed. Farther caudalward, at planes in which the replacement of pars dorsalis by neopallial cortex is occurring, pars ventralis forms the gray of the ventromedial angle of the hemisphere (fig. 5) and is gradually replaced by the olfactory tubercle (fig. 6).

In a plane just caudal to the accessory bulb and immediately dorsal to pars dorsalis of nucleus olfactorius anterior, a group of cells appear corresponding to the pars externa of Gurdjian ('25, rat), Young ('36, rabbit), Humphrey ('36, bat), Crosby and Humphrey ('39, red squirrel, mouse, weasel, pig, short-tailed shrew and mole) and Fox ('40, cat). According to Crosby and Humphrey, no clean-cut differentiation of pars externa has been found in man, although possible representation of this part of nucleus olfactorius anterior is to be found in scattered cells which occur at various levels of the crus. "This lack of development of what in many forms is a conspicuous portion of the nuclear complex is probably related to the absence of an accessory olfactory bulb in man" (Crosby and Humphrey, '41). In the mink, pars externa forms a semi-circular band (fig. 4) above the dorsal portion of the anterior olfactory nucleus and, in rostral sections, consists chiefly of a layer of neurons about four or five cells thick, with the cells rather loosely arranged. A narrower, more compact medial group of cells representing pars externa is present at a slightly more caudal plane. This group joins the remainder of the nucleus but persists only through a few sections. Just caudal to the appearance of this medial group 
of pars externa, the most dorsal portion of pars externa thins out; the dorsolateral portion extends ventralward and then the most dorsal and the medial portions disappear simultaneously. However, in some more caudal sections, there are intermittent, small, scattered groups of cells ventromedially placed, which may be part of pars externa. Still more caudalward there is only a small pars externa lateral to the region of union of pars lateralis and pars ventralis of the anterior olfactory nucleus and somewhat fused with them. It was not possible to trace pars externa in the mink entirely around the olfactory ventricle. It seems evident that it does not form a complete ring as it does in some other mammals (Crosby and Humphrey, '39).

The remaining subdivision of nucleus olfactorius anterior, its pars posterior, is illustrated in figure 5. It appears rostrally as scattered, more deeply staining neurons in the relatively undifferentiated periventricular gray, ventral to the ventricle of the olfactory crus. Its cells rapidly increase in number until there is a considerable nuclear mass (fig. 5) internal to pars ventralis of the anterior olfactory nucleus. As the olfactory tubercle develops, its inner layer replaces the ventral part of pars posterior and nucleus accumbens replaces the dorsal and most caudal part of pars posterior. This portion of the anterior olfactory nucleus has been described in various mammals by Obenchain ('25, Caenolestes and Orolestes), Crosby and Humphrey ('39, a considerable range of mammals), Fox ('40, cat) and others.

\section{Olfactory tubercle}

The olfactory tubercle of the mink exhibits a more primitive pattern than does that of the cat (Fox, '40), in having a convoluted pyramidal layer and highly developed islands of Calleja. In figure 6 the various layers of the olfactory tubercle - the plexiform layer, the pyramidal layer and the polymorph layer - are illustrated. This layer arrangement is based on the descriptions of the olfactory tubercle (tuberculum olfactorium) by Calleja (1893), Beccari ('10) and Ramón $y$ Cajal ('11). The olfactory tubercle of the mink is bounded rostrodorsally by pars posterior of the anterior olfactory nucleus and replaces the deep portion of pars ventralis of this same nuclear gray. As pars posterior disappears, the tubercle is bounded dorsally by the caudate nucleus and nucleus accumbens, medially by the anterior continuation of the hippocampus and the medial septal nucleus and laterally by the piriform lobe. Caudally it is replaced by the diagonal band of Broca.

The deep portion of the olfactory tubercle replaces pars posterior and the dorsal portion of pars ventralis of the anterior olfactory nu- 
cleus, just rostral to the level of figure 6 . This deep portion is known as the polymorph layer. Its neurons are of several types: scattered small granule cells, spindle-shaped cells, medium-sized and large, deeply stained pyramidal cells and dense nuclear groups forming the islands of Calleja. The dorsal portion of the polymorph layer is not distinct from the bordering cells of the caudate nucleus nor is it definitely delimited ventrally from the pyramidal layer of the olfactory tubercle.

The pyramidal layer may be seen in figures 6 and 7 . It is made up of compact, deeply stained granule cells and medium and small sized pyramidal cells, arranged in a scalloped or convoluted pattern. This layer stands out particularly since the plexiform layer of the olfactory tubercle, immediately ventral to it in position, is composed of lightly stained granule cells and fibers.

The small islands of Calleja (fig. 7) are located in the polymorph layer and appear as globular groups of compactly arranged, deeply stained granule and pyramidal cells. These.small islands extend as scattered nuclear groups from the dorsomedial to the dorsolateral portion of the olfactory tubercle. Individually they appear in two to six successive $25 \mu$ sections; then they fade out and other such groups make their appearance.

The giant island of Calleja (fig. 7), located between nucleus accumbens and the lateral and medial septal nuclei, is also composed of deeply stained granule and pyramidal cells. Central depressions may be seen in this giant island from which fibers emerge (fig. 7). The bulk of the giant island is continuous with the polymorph layer but its most ventromedial border blends into the medial cells of the pyramidal layer of the olfactory tubercle.

Since the time of Ramón y Cajal ('11), the olfactory tubercle has been studied and described in several mammals, by Obenchain ('25) and Loo ('31) for marsupials, Gurdjian ('25) and M. W. Young ('36) for rodents, Humphrey ('36) for the bat, and Crosby and Humphrey ('39 and '41) for various mammals and man.

\section{Amygdaloid complex}

The mammalian amygadaloid area has been studied by Johnston ('23, opossum), Obenchain ('25, Caenolestes and Orolestes), Berkelbach van der Sprenkel ('26, opossum), Olive Smith ('30, Tamandua), Humphrey ('36, bat), Young ('36, rabbit), Fox ('40, cat), Crosby and Humphrey ('41, man), Lauer ('45, macaque) and others. In general the pattern recognized in our material resembles closely that laid down by these earlier observers, although there are some minor differences. 
For example, Young and Fox did not describe an accessory basal amygdabid nucleus such as the amygdaloid region in the mink shows. Moreover, in the mink no doubling of the nucleus of the lateral olfactory tract, such as was described in the opossum (Obenchain), the bat (Humphrey), the macaque (Lauer) and man (Crosby and Humphrey), was recognized. In general the cortico-medial group is proportionately larger and the baso-lateral group correspondingly smaller in the mink than in primates.

The amygdaloid area can be subdivided into several distinct nuclear groups, most of which are clearly represented in figures 12 and 13. These various nuclear groups, as they have been recognized and named in other animals, are the lateral, the basal, the accessory basal, the central, the medial and the cortical amygdaloid nuclei, the nucleus of the lateral olfactory tract, the anterior amygdaloid area and the intercalate masses. The rostral border of the amygdala is just cephalad to figure 11. In this figure, the nucleus of the lateral olfactory tract, the anterior amygdaloid area and the intercalate masses may be seen. The caudal border of the amygdala is just behind figure 14, in which remnants of nearly all the main nuclei can still be recognized. In this figure there are a few of the large cells of the central nucleus interspersed between the fibers of stria terminalis, just medial to the tail of the caudate nucleus. Lateral to the tail of the caudate is a group of large cells of the lateral nucleus. These are separated from the smallcelled portion of the lateral amygdaloid nucleus by the hippocampus. Ventral to the hippocampus, the cells of the small-celled portion of the lateral and the large-celled portion of the basal nuclei are so intermingled as to appear as a single nuclear mass. The accessory basal amygdaloid nucleus lies ventromedial to the basal amgydaloid nucleus and is continuous with the dorsolateral border of the cortical amygdaloid nucleus which, in turn, is continuous ventrolaterally with piriform lobe cortex and medially with the most caudal part of the medial amygdaloid nucleus. For descriptive purposes, and in accordance with the plan adopted by many observers (Fox, '40, for example), the amygdaloid nuclei are placed together in three groups - (a) an anterior amygdaloid area; (b) a basolateral group composed of the lateral, the basal and the accessory basal nuclei, and (c) a cortico-medial group comprised of the cortical, the medial and the central amygdaloid nuclei and the nucleus of the lateral olfactory tract.

Anterior amygdaloid group. Sections rostral to and including figure 11 show the anterior amygdaloid area, which lies ventral to and almost indistinguishable from substantia innominata. The anterior amygdaloid 
area is replaced in more caudal sections by the ventral, small-celled portion of the lateral amygdaloid nucleu's, the medial amygdaloid nucleus and the basal and the accessory basal amygdaloid nuclei.

Cortico-medial amygdaloid group. The nucleus of the lateral olfactory tract does not extend so far forward as the rostral pole of the anterior amygdaloid area. However, in levels rostral to figure 11 it has replaced a portion of the anterior amygdaloid area. In figure 11 the nucleus of the lateral olfactory tract appears as a large compact mass of darkly stained cells, similar in size and structure to the deep cortical cells of the piriform lobe. It is continuous rostrocaudally, exhibiting none of the secondary divisions described for other forms. In planes illustrated in figures 12 and 13, the nucleus of the lateral olfactory tract has been replaced by the cortical amygdaloid nucleus laterally and by the ventral part of the medial amygdaloid nucleus medially.

The medial amygdaloid nucleus appears as a triangular mass, the apex and dorsomedial side of which border cells of the entopeduncular nucleus or remnants of the nucleus of the diagonal band of Broca. The ventrolateral part of the medial amygdaloid nucleus replaces the nucleus of the lateral olfactory tract and its basal portion is continuous with the medial part of the anterior amygdaloid area. In figure 12 the medial amygdaloid nucleus merges with the cortical amygdaloid nucleus ventrolaterally and lies along the medial surface of the temporal pole. Farther caudalward (fig. 13) the medial amygdaloid nucleus is bordered by the central amygdaloid nucleus dorsolaterally, the basal and the accessory basal nuclei laterally and the cortical nucleus ventrally. The medial nucleus is replaced caudally by the hippocampal cortex just behind the level of figure 14 .

The rostral end of the cortical amygdaloid nucleus replaces the lateral portion of the nucleus of the lateral olfactory tract. Its position in relation to the medial nucleus has been described. It is continuous laterally with the piriform lobe cortex (figs. 12 and 13) which ultimately replaces it, and always lies in intimate relation with it until replaced.

The central amygdaloid nucleus in the mink is divisible into a largecelled medial portion which resembles globus pallidus and a smallcelled lateral portion which resembles the putamen. 'Rostrally the smallcelled part is almost indistinguishable from the putamen (fig. 12). Gradually the central nucleus is separated from the putamen by a downward extension of globus pallidus (fig. 13). The caudal tip of the central nucleus lies medial to the caudate nucleus (fig. 14). 
Basolateral amygdaloid group. The lateral amygdaloid nucleus makes its appearance between the external capsule and the putamen, somewhat rostral to the plane of figure 12. It exhibits two parts in figures 12 and 13: (a) a large ventral, small-celled portion, capped by (b) a small triangular group of larger, darker cells. The lateral and basal amygdaloid nuclei terminate simultaneously just a few sections behind the plane of figure 14.

The basal amygdaloid nucleus appears just medial and a few sections caudal to the rostral tip of the lateral nucleus. It exhibits a dorsolateral larger-celled, darkly stained portion and a ventromedial small-celled lightly stained portion (figs. 12 and 13). This small-celled component is intermingled with the dorsolateral border of the cortical amygdaloid nucleus (fig. 13). The accessory basal amygdaloid nucleus is composed of seattered small cells lying medial to the large basal amygdaloid nucleus. In figure 13 the relations of the accessory basal nucleus to the basal, central, medial and cortical amygdaloid nuclei can be seen. The basal and accessory basal nuclei for most of their extent are ventral to the central nucleus (figs. 12 and 13). They lie below the hippocampus at caudal levels (fig. 14).

Intercalate masses. The intercalate masses are scattered through the anterior amygdaloid area, beginning cephalad to figure 11 as compact clumps of small, darkly-stained cells. Several of them appear in figure 11; one large mass spreads out medially in caudal levels and lies below the lateral amgydaloid nucleus; other smaller masses appear in the most medial part of the area. In figure 12 there is a rather large intercalate mass wedged in between the basal and the central amygdaloid nuclei.

\section{Septal area}

The septal area is bounded rostrally by the caudal end of pars posterior of the anterior olfactory nucleus (fig. 5) and caudally by the crossing of the anterior commissure (fig. 10). The septal area is bounded dorsally by corpus callosum, ventrally by the olfactory tubercle and laterally by the two lateral ventricles (fig. 6). The area (figs. 7 to 10) is subdivided into: (1) the medial septal nucleus, (2) the lateral septal nucleus, (3) the septo-hippocampal nucleus, (4) the bed nucleus of the anterior commissure, (5) nucleus accumbens septi and (6) the nucleus of the diagonal band of Broca.

Among the people who have considered the precommissural and postcommissural septal areas in mammals are Obenchain ('25), Gurdjian ('25), A. Young ('26), Loo ('31), Humphrey ('36), M. Young ('36) and 
Fox ('40). The relations of the various nuclei of the septal area in the mink resembles those described by these authors for other mammals.

Medial septal nucleus. The medial septal nucleus makes its appearance rostrally, between the ventral tip of the anterior continuation of the hippocampus and the dorsomedial portion of the olfactory tubercle. It expands rapidly in a dorsal direction at the expense of the lower part of the anterior continuation of the hippocampus (fig. 7). Farther caudalward (figs. 8 and 9) the anterior continuation of the hippocampus disappears and the medial septal nuclei of each side lie ventromedial to the lateral septal nuclei. In its greatest extent the medial septal nucleus shows an indistinct division into dorsal and ventral portions (fig. 9 ). The dorsal portion passes over without demarcation into the gray constituting the bed nucleus of the hippocampal commissure. The ventral portion (figs. 7 and 8) blends with the dorsomedial part of the nucleus of the diagonal band of Broca, which replaces it. The cells of the medial septal nucleus are small, show no differential staining, and are somewhat scattered in arrangement.

Lateral septal nucleus. The lateral septal nucleus makes its appearance a few sections rostral to the medial septal nucleus. It consists of a dorsal group of neurons between the most dorsal part of the anterior continuation of the hippocampus and the lateral ventricle and a ventral group medial to the caudate nucleus and ventral to the ventricle. As these two groups expand they form a distinct nuclear mass (figs. 7 and 8) which lies parallel and adjacent to the medial septal nucleus. Farther caudalward (fig. 9) the ventral portion of the lateral septal nucleus is squeezed in between the medial septal nucleus and the giant island of Calleja. The island separates the lateral septal nucleus from nucleus accumbens. Caudalward the ventral cells of the lateral septal nucleus not only adjoin those of nucleus accumbens but resemble them in structure, and in the most caudal sections these two nuclei, as well as the bed nuclei of the anterior commissure, are indistinguishable from each other (fig. 10). The more dorsal cells of the lateral septal nucleus are larger, slightly darker stained and more scattered in arrangement, and they resemble the adjoining cells of the septo-hippocampal nucleus (fig. 9).

Septo-hippocampal nucleus. The septo-hippocampal nucleus (figs. 8 and 9) makes its appearance at about the same level as does the giant island of Calleja and in about the same plane as the lateral septal nucleus. It occupies the most dorsal part of the caudal septal area immediately below corpus callosum. Caudally it lies lateral to the anterior continuation of the hippocampus, replacing the dorsal portion of the latter 
as well as the dorsocaudal portions of the lateral and the medial septal nuclei. It continues caudally until it passes directly into the hippocampus, in transverse planes caudal to the preoptic area. This backward continuation of the nucleus is represented at many levels by only two or three cells, yet careful study indicates that it is present at all such levels.

Bed nuclei of anterior commissures. The bed nuclei of the anterior commissure first appear as a few cells close to, and ventrolateral to, the anterior extension of this commissure. As one proceeds caudally these cells increase in number and distinctness extending medially and then dorsally so that just before the crossing of the commissure they incompletely surround it. In figure 10, which shows the actual decussation, the bed nuclei form two distinct groups in the midline, one dorsal, the other ventral to the commissure. The dorsal group is subdivided into a medial and a lateral portion by the fibers of stria terminalis. The lateral part resembles the lateral septal nucleus and may be regarded as a continuation of this latter. The medial part grades over into the medial septal nuclear group (fig. 10).

Nucleus accumbens. Nucleus accumbens is so intimately related to the caudate nucleus and resembles it so much in structure that it is hard to delimit one from the other. Consequently, it is customary to call that portion nucleus accumbens, which lies medial to a plane cutting dorsoventrally through the tip of the ventricle, and to term the part which lies lateralward, the caudate nucleus. Near its rostral limit nucleus accumbens (figs. 6 and 7) is bounded dorsally and medially by the frontal cortex and the lateral septal nucleus from which latter it is scarcely distinguishable in some planes. Ventrally the olfactory tubercle borders nucleus accumbens and laterally the caudate nucleus. Slightly farther caudalward (figs. 7 and 9) the giant island of Calleja intervenes between nucleus accumbens and the lateral septal nucleus. The ventricle, the interbulbar component of the anterior commissure and the caudate nucleus form the lateral boundary of nucleus accumbens.

Nucleus of diagonal band of Broca. The nucleus of the diagonal band of Broca (figs. 6-9) lies ventral to the ventral tip of the giant island of Calleja. It is continuous dorsally and dorsomedially with the medial septal nucleus and laterally is intermingled with and replaces the polymorph layer of the olfactory tubercle. In company with its fiber bundles it passes over the caudal pole of the olfactory tubercle and extends into the region of substantia innominata, globus pallidus, the putamen and the anterior amygdaloid area with all of which it is intermingled (fig. 11). 


\section{Preoptic area}

The name, preoptic area, is given to the region which lies on either side of the preoptic recess, from a plane ventral to the anterior commissure to the level of the optic chiasm (figs. 10 and 11). It has been subdivided into three nuclear areas: (1) the periventricular gray, bordering on the anterior continuation of the third ventricle or preoptic recess, (2) the lateral preoptic area, which extends out laterally to the hemisphere gray and (3) the medial preoptic area, which lies between the periventricular gray and the lateral preoptic area.

In figure 10 directly in the midline, between the crossing of the anterior commissure and the optic chiasm, is a thin streak of ependymal cells marking the rostral wall of the preoptic recess. The ventricle itself appears a few sections caudalward. At the dorsal tip of this ependymal streak the ventral part of nucleus triangularis septi (not labeled) appears as a triangle under the commissure. The dorsal part overlies the commissure. The cells of the bed nuclei merge throughout with this triangular mass of gray, the apex of which is directed dorsally. This nucleus triangularis septi is bisected by the streak of ependyma. The ventral portion of nucleus triangularis septi corresponds to nucleus preopticus medianus of Loo ('31). Farther caudalward, as the ventricle appears, this cell mass is replaced by the periventricular gray (fig. 11), which later, as it lies dorsal to the chiasm, is replaced by cells of the suprachiasmatic nucleus. The periventricular gray of the preoptic area passes over without any marked change into the periventricular gray of the hypothalamus.

The lateral preoptic area is bounded both by dorsolateral extensions of the diagonal band of Broca and by ventrolateral strands of somewhat smaller and less scattered cells, which extend into the amygdaloid area. At the caudal extreme of the preoptic area, the compact cells of nucleus supraonticus (figs. 10 and 11) occupy a position around the fibers of the optic tract. In more rostral sections cells of a similar type are found in the medial preoptic area with some cells intermingling in the periventricular gray extending up to nucleus paraventricularis. The lateral preoptic area and the diagonal band of Broca are indistinguishable rostrally and the lateral area goes over without marked change into the lateral hypothalamic region caudally, its limits being arbitrarily set.

The medial preoptic area (figs. 10 and 11) contains larger cells than those in the periventricular gray but not so large and much more compactly arranged than the cells of the lateral area. There is no fine line 
of demarcation between the three areas, their differences being due to . cell size and arrangement. However, in figure 11 the medial area is quite distinct. The compact cells are dark-stained and are continuous dorsally with those of the bed nuclei of the commissure. Uniting the two groups, in transverse sections, is a diagonal cell band which extends around the lateral border of the anterior commissure to the periventricular gray as it spreads out over the chiasm. It accompanies fibers of stria terminalis and is spoken of as the bed nucleus of the stria (fig. 11). Caudally the medial preoptic area grades over into the medial area of the hypothalamus.

\section{DESCTIPTIONS OF FIBER CONNECTIONS}

\section{Olfactory and vomeronasal nerves}

The fibers of the unmedullated olfactory nerves to the olfactory formation exhibit the sector distribution mentioned in the description of the nuclear material for these areas (figs. 3 and 15). This nerve has been repeatedly described and illustrated for various mammals (for example, by Ramón y Cajal, '11, McCotter, '12 and Herrick, '24). The vomeronasal nerve is medium-sized in the mink. After passing along the medial side of the bulb this nerve reaches the accessory olfactory formation, which lies on the dorsal surface at the caudal end of the olfactory bulb. This nerve likewise has been studied by several observers (McCotter, '12, Crosby and Humphrey, '39, and others).

\section{Lateral olfactory tract}

The most rostral well defined fibers of the lateral olfactory tract arise from cells in the dorsal sector of the bulb, with contributions from its dorsomedial and lateral cells appearing more caudally (fig. 15). The fibers of the lateral olfactory tract from the medial portion of the bulb merge more or less with those of the medial olfactory tract. However, the former can be distinguished because they are directed dorsalward. In more caudal planes there are interchanges between the dorsal fibers of the interbulbar component of the anterior commissure and those of the lateral olfactory tract. Toward the caudal end of the bulb, the olfactory formation contributes to the lateral olfactory tract and there is a very large contribution from the accessory bulb dorsally and from the lateral portion of the olfactory bulb laterally. Figure 15 shows the intermingling of fibers of the medial olfactory tract, the interbulbar component of the anterior commissure and the lateral olfactory tract. 
In levels somewhat caudal to figure 15 , there is a small contribution. from the ventral portion of the bulb to the lateral olfactory tract. As the various parts of the anterior olfactory nucleus take shape, there are fiber connections between the lateral olfactory tract and the cells of pars dorsalis, pars lateralis, pars externa, pars medialis, and pars ventralis of this nucleus, as well as some connection with the olfactory tubercle as it replaces pars ventralis.

The relations of the lateral olfactory tract and the amygdaloid areas (the cortical amygdaloid nucleus and the nucleus of the lateral olfactory tract) are given in detail in the description of the fiber connections of the amygdala. The intermingling of the fibers of the diagonal band of Broca with those of the lateral olfactory tract is described under the diagonal band connections. Caudally the lateral olfactory tract sweeps around the periphery of the hemisphere into the piriform lobe.

The lateral olfactory tract has been studied in a wide range of submammals (Herrick, '10; Johnston, '15; Crosby, '17; Herrick, '33; Ariëns Kappers, Huber and Crosby, '36), and of mammals (Hines, '29, for Ornithorhynchus; Herrick, '24, Obenchain, '25, and Loo, '31, for marsupials; Winkler and Potter, '11; Gurdjian, '25 and '27, and M. Young, '36, for rodents; Winkler and Potter, '14, and Fox, '40, for carnivores; Humphrey, '36, for chiropters, and Beccari '10, Klass, '29, and many others for man).

\section{Medial olfactory tract}

The most rostral portion of the medial olfactory tract appears at about the same level as does the lateral olfactory tract. It arises from cells in the medial and dorsomedial part of the olfactory formation (fig. 15). Fascicles join it from the accessory olfactory bulb. There is an intermingling of fibers of the medial olfactory tract and the lateral olfactory tract in the ventral part of the crus (fig. 15). Pars ventralis of the anterior olfactory nucleus and the olfactory tubercle are both contributed to by the medial olfactory tract which then passes to the anterior continuation of the hippocampus. This tract has been described by practically the same group of observers as were quoted as having studied the lateral olfactory tract.

\section{Anterior commissure}

Among the many observers who have studied intensively the various components of the mammalian anterior commissure mention should be 
made of Ramón y Cajal ('11), Johnston ('23), Sonntag and Woollard ('25), Gurdjian ('25), Berkelbach van der Sprenkel ('26), Olive Smith ('30), Loo ('31), Young ('36), Humphrey ('36), Fox ('40) and Ariëns Kappers, Huber and Crosby ('36).

Interbulbar and interlobar component. The interbulbar component of the anterior commissure (intermediate olfactory tract of some authors) begins dorsal and dorsolateral to the olfactory ventricle, receiving the bulk of its fibers in this rostral region from the lateral part of the olfactory formation. The accessory olfactory bulb also contributes to this tract (fig. 15). Passing caudalward this interbulbar component receives in order fibers from $(\cdot a)$ the accessory olfactory bulb, (b) pars lateralis, pars externa, pars medialis, pars ventralis (and possibly a few fibers also from pars dorsalis) of the anterior olfactory nucleus and (c) the olfactory tubercle. There is an interchange of fibers between the interbulbar and interlobar components in the anterior commissure and the medial forebrain bundle. Rostral to the appearance of the external capsule division of the intertemporal component of the anterior commissure (fig. 17), the fibers of the interbulbar and interlobar components are joined by fascicles from the internal capsule.

Intertemporal component. The intertemporal component included the lateral interamygdaloid, the basal interamygdaloid and the external capsule components described in the bat (Humphrey, '36). The mink exhibits a small external capsule component as compared with the other components of the anterior commissure. This small sized bundle corresponds to that of the external capsule component in the edentate, Orycyteropus (Sonntag and Woollard, '25), but differs in size from that described in the bat (Humphrey, '36) and the opossum (Loo, '31). Rostrally the larger intertemporal component (fig. 17) interconnects the lateral parts of the anterior olfactory nuclei and more caudally the piriform lobes. It also intermingles with fibers of corpus callosum from neopallial cortex. In more caudal planes this bundle is intermingled with fibers connecting the piriform lobe and the hippocampus. The lateral and the basal interamygdaloid components are described under the amygdaloid fiber connections.

Stria terminalis component. The stria terminalis component of the anterior commissure is composed of medial and cortical interamygdaloid bundles and fascicles to and from the nuclei of the lateral olfactory tract (fig. 18). This component is described in more detail under the amygdaloid connections. 


\section{Fiber connections of amygdaloid complex}

The most rostral, well defined fiber connections of the amygdaloid nuclei are evident in figures 17 and 18. At this level lies the rather undifferentiated gray which makes up the anterior amygdaloid area (compare fig. 11). From it the fascicles pass dorsally to become a part of the intertemporal component of the anterior commissure (fig. 17). Other fascicles enter or leave the anterior amygdaloid area through the diagonal band of Broca (fig. 18).

The nucleus of the lateral olfactory tract is well defined at this same level and the fibers joining it from the diagonal band are demonstrable (fig. 18). The nucleus of the lateral olfactory tract is also a nucleus of termination for the fibers of this tract (fig. 16), from which it receives its name. The terminal fibers of the lateral olfactory tract and fibers of the diagonal band appear to form a capsule around this nucleus. Also a small discrete bundle can be traced dorsocaudalward from the nucleus of the lateral olfactory tract, passing through or near the central amygdaloid nucleus to a position between the bed nucleus of stria terminalis and the caudate nucleus. This bundle runs with the other components of stria terminalis until it nears the anterior commissure, where it leaves the stria and enters the commissure (fig. 18). The bundle corresponds to Johnston's ('23) commissural bundle of stria terminalis.

Fibers of the diagonal band of Broca come into relation with the medial amygdaloid nucleus (figs. 19 and 20), and possibly with the central and the larger celled part of the basal nucleus. From the medial amygdaloid nucleus, fascicles swing dorsally to enter stria medullaris (fig. 20). Such a connection has been described by M. W. Young ('36) for the rabbit and Marburg ('44) for man. From the medial nucleus fibers turn dorsolateralward to form the nucleus tractus olfactorius lateralis component of stria terminalis on its medial side (fig. 20). The two components in company with fascicles from the cortical and central amygdaloid nuclei (and apparently also from the basal accessory) form a common bundle which sweeps caudodorsalward to meet the tail of the caudate nucleus. From this position the bundle accompanies the caudate dorsocaudally and then rostrally (fig. 19) until the plane of the anterior commissure is reached (fig. 18). Here the bundles leave the caudate, swinging ventralward and slightly ventromedialward. The nucleus tractus olfactorius lateralis component crosses in the commissure, as do other fascicles of stria terminalis. Other bundles, 
either with or without crossing, pass to the preoptic and to the hypothalamic areas.

The cortical amygdaloid nucleus (fig. 18) receives, along its medial border, fascicles of the lateral olfactory tract (fig. 18). It also contributes fibers to stria terminalis. These fibers join the lateral side of nucleus tractus olfactorius lateralis component of the stria (fig. 20) and follow it dorsalward and caudalward and then forward in the course just described for the component of the stria from the medial amygdaloid nucleus.

Basal, accessory basal and central amygdaloid nuclei also contribute to the component from the cortical nucleus to stria terminalis. The central amygdaloid nucleus, as was mentioned previously, sends fibers to the lateral cortico-habenular component of stria medullaris (fig. 20). In addition to their contribution to stria terminalis, the basal and accessory basal as well as the lateral amygdaloid nuclei give out and receive fibers through the intertemporal component of the anterior commissure (fig. 17), described under the account of that commissure.

The amygdaloid connections in mammals have received considerable consideration. For example, they have been studied in the opossum by Johnston ('23) and Berkelbach van der Sprenkel ('26), in Orycteropus by Sonntag and Woollard ('25), in rodents by Gurdjian ('25) and Young ('36), in the bat by Humphrey ('36), in the cat by Fox ('40), in Tamandua by Olive Smith ('30), and in the monkey by Lauer ('45).

\section{Diagonal band of Broca}

In the more rostral planes in which the diagonal band of Broca appears, it receives fibers from the olfactory tubercle (fig. 17). Throughout its extent it is in synaptic relation with the accompanying cells which constitute its nucleus. In figure 17 the diagonal band of Broca sweeps ventralward intermingling with fibers of the medial forebrain bundle. The diagonal band is connected with globus pallidus and with the supraoptic nucleus. Its relations to the anterior amygdaloid area, nucleus of the lateral olfactory tract, and medial and cortical nuclei of the amygdala are described in the consideration of the amygdaloid connections. The more caudal fascicles of this bundle are indistinguishably intermingled with the amygdaloid components to stria medullaris thalami and stria terminalis.

The diagonal band has been recognized by most observors who have studied this region. Special mention mav be made of Johnston ('23) and van der Sprenkel ('26) who described its relations to the amygdaloid 
complex in the opossum. Young ('36), Humphrey ('36) and Fox ('40) gave accounts of this system in the rabbit, the bat, and the cat respectively, stressing its connections with the piriform lobe and the anterior amygdaloid area.

\section{Fornix}

The origin, path and termination and the various divisions of the fornix have been studied and described by many authors. A comprehensive summary of the various findings is given in detail in the text by Ariëns Kappers, Huber and Crosby ('36).

Precommissural fornix. Rostrally the fibers of the precommissural fornix are intermingled with those of the internal capsule, the medial forebrain bundle and the external capsule component of the anterior commissure. In figure 16 some of its fibers cross in the hippocampal commissure. Its relationship to nucleus accumbens, the lateral septal nucleus and the olfactory tubercle may be seen in the same figure. The fibers ( $T$, fig. 17) of the precommissural fornix which decussate to interconnect the olfactory tubercles (the intertubercular commissure) lie somewhat caudal to this level. Some fibers of the diagonal band of Broca are intermingled with those of the fornix just rostral to the decussation of the anterior commissure. Fibers forming the white stria of Lancisi can be distinguished but, in the available material, no perforating fibers were discerned.

Postcommissural fornix. Just behind the anterior commissure there is an intermingling of the fibers of the fornix columns with those of long association bundles. At this level the chief contribution to the fornix is from the cingulate gyrus. These fibers can be readily distinguished because of their darker staining properties from the lightly stained fibers of stria medullaris component of the postcommissural fornix. These lighter, finer fibers form the medial cortico-habenular tract (fig. 19). The postcommissural white stria of Lancisi can be seen at the same level. Perforating fibers are barely visible in a somewhat caudal plane. The septo-habenular tract from the bed nucleus of the hippocampus and the medial septal nucleus to the habenula could be followed, although with some difficulty. In figure 23 there is a small ventral decussation (fornix commissure) of fornix fibers below the mammillary bodies. Rostral to this commissure the mammillo-thalamic tract lies adjacent to the mammillary bodies just caudal to the small ventral commissure of the fornix. In more rostral planes, cortico-hypothalamic fibers from the columns of the fornix spread out lateral to the mam- 
millary bodies and terminate in this hypothalamic area. In figure 16 the dorsal commissure (hippocampal commissure) may be seen, and also its contribution from the alveus (pars alvearis of Loo, '31). The component from the fimbria (pars fimbriae of Loo, '31) appears in more caudal planes.

\section{Stria medullaris}

The medial cortico-habenular tract described by many workers, for example, Gurdjian ('25), Loo ('31), Young ('36) and Humphrey ('36) is easily discernible in figures 19 and 20. The other components of stria medullaris, and their relationships to other fiber bundles, were difficult to trace in the available material. There is such extensive intermingling of the fibers of stria medullaris with those of the diagonal band of Broca, the medial forebrain bundle, stria terminalis and the lateral olfactory tract component of the anterior commissure that it is difficult to determine whether it is intermingling or an interchange of fibers. However, the following connections were noted.

a. Tractus olfacto-habenularis anterior of Herrick ('33). Fibers from the olfactory tubercle first pass dorsomedially then fan out, some sweeping dorsally to perforate nucleus accumbens and then turning medially to decussate in the hippocampal commissure. Other fibers sweep along the septal border intermingled with the medial forebrain bundle, then pass dorsally and join fibers from the septal nuclei. Some of these latter may cross in the intertubercular component of the hippocampal commissure, others join the fornix and may be followed caudally in this bundle until they enter stria medullaris by which they pass to the habenula (fig. 16). Herrick ('33) has described this track for Necturus and Marburg ('44) for man.

b. Tractus septo-habenularis. In figures 16 to 20 , a bundle, the fibers of which are related to the septo-hippocampal nucleus and medial and lateral septal nuclei, can be followed from the precommissural septal regions caudalward until it enters stria medullaris. This component has been described by Gurdjian ('25), Humphrey ('36), M. W. Young ('36), Marburg' ('44)' and others.

c. Tractus preopticus habenularis. This tract includes tractus precpticus supraopticus of Loo ('31). Fibers from the preoptic nuclei (periventricular gray, medial preoptic nucleus and supraoptic nucleus) pass dorsally not far from the ventricle in planes slightly caudal to figure 20. They swing medial and then dorsal to the fornix to enter stria medullaris on its ventromedial border. 
d. Amygdalo-habenular component of stria medullaris. This connection has been described under the account of the fiber connections of the amygdaloid complex as part of the lateral cortico-habenular system (page 190).

e. Stria terminalis component of stria medullaris. At the level of figure 20, fibers from stria terminalis swing ventromedialward to enter the upper lateral border of stria medullaris. Their position is indicated by $\mathrm{x}$ on the figure. They are so small in number and so fine that they do not show in photomicrographs although they are recognizable in the material. Such a connection has been described by various observers, M. W. Young ('36) among others.

\section{Stria terminalis}

The various components of stria terminalis (figs. 18 to 20), so far as the material permitted their recognition, have been described under the accounts of the connections of the amygdaloid complex and the components of stria medullaris. Such descriptions need not be reported here. In its course stria terminalis lies for most of its extent in its usual position in relation to the caudate nucleus. It is presumably a discharge path for the amygdaloid complex. It is accompanied through much of its extent by a very small and somewhat inconstant bed nucleus which follows the spread of its fibers at anterior commissure levels to fuse with the bed nucleus of the commissure.

\section{Medial forebrain bundle}

In the opossum Loo ('31) described fascicles of the medial forebrain bundle as far forward as the olfactory bulb. The most rostral component discernible in the mink appears in the region of the olfactory tubercle, increasing in size in succeeding caudal planes. It receives definite fascicles frm the septal nuclei, particularly from the ventromedial part of the septal area and also from nucleus accumbens. The fibers of the medial forebrain bundle intermingle with those of the precommissural fornix (fig. 17) and those of the diagonal band of Broca (fig's. 16 and 17). The medial forebrain bundle passes under the anterior commissure (fig. 18) into the lateral preoptic area (figs. 19 and 20) and then swings caudalward (fig. 21) to its termination in the hypothalamus. Perhaps this bundle has connections with the tegmentum of the midbrain but the most caudal part of its course was not followed in this study. 
The olfactory bulb in the mink shows the pattern characteristic for mammals, including segment formation. It has a rather small but distinctly developed accessory bulb.

The anterior olfactory nucleus exhibits all of the parts which have been described in other mammals, including pars posterior. The main nuclear mass shows a complete ring around the ventricle with pars externa forming an incomplete ring. The fiber connections indicate that the anterior olfactory nucleus is an internode in the course of the medial and the lateral olfactory tracts, both of which are quite well developed.

The large medial or giant island of Calleja of the olfactory tubercle and also the smaller, more scattered islands of the region are composed of both pyramidal and granule cells. In addition to the interconnections from the septal area and the usual components to the precommissural fornix, there are bundles from the two olfactory tracts. Tuberculoamygdaloid, tukerculo-habenular and an intertubercular consponent to the anterior commissure are recognized.

The lateral septal and the medial septal nuclei show secondary subdivisions. As in all mammals they are intercalated along the course of the fibers passing to and from the hippocampus by way of the fornix, the diagonal band of Broca, the medial forebrain bundle and associated systems. The mink is one of the forms in which the septohippocampal nucleus is continuous, extending from the anterior continuation of the hippocampus, through the septal area and rejoining the hippocampus in the region of the splenium of corpus callosum. It is vestigial hippocampal gray ventral to corpus callosum as indusium griseum is hippocampal gray dorsal to this neopallial commissure.

The amygdaloid complex of the mink, in degree of nuclear differentiation and associated specificity of fiber connnections, is intermediate between that found in other carnivores, such as the cat and the dog, and that seen in certain primates such as the macaque. The corticomedial portion of the amygdala, like that in other carnivores, is well differentiated, a condition related to the relatively well developed olfactory system. In the mink the amygdala has a characteristic but undivided nucleus of the lateral olfactory tract. The latero-basal part of the amygdaloid complex is proportionally somewhat larger in this form than in other carnivores and shows greater secondary differentiation. Lateral, basal and accessory basal amygdaloid nuclei are present and each one shows traces of secondary subdivision. The fiber connec- 
tions of the latero-basal portion of the amygdala resemble those seen in primates although on the whole they are smaller and rather less clear cut. Thus the pattern approaches that seen in primates although the nuclear masses and the fiber connections are smaller.

The telencephalon of the mink is intermediate in development between that of other carnivores and of primates and in this fact lies its chief importance to the comparative neurologist. Particularly in the degree of differentiation of its amygdaloid complex but also in the continuity of its septo-hippocampal nucleus and in certain relations of its olfactory tubercle, it furnishes useful information concerning forebrain evolution.

\section{LITERA'IURE CITED}

ARIËNS KaPpers, C. U., G. C. HuBER AND E. C. CRosbY 1936 The comparative anatomy of the nervous system of vertebrates, including man. The Macmillan Co., New York.

BECCARI, N. 1910 Il lobo parolfattorio nei mammiferi. Arch. ital. di anat. e di embriol., vol. 9, pp. 173-220.

Berkelbach VAN Der SPRENKEL, H, 1926 Stria terminalis and amygdala in the brain of the opossum, Didelphis virginiana. J. Comp. Neur., vol. 42, pp. 211-254.

CAJAL, See Ramón y Cajal.

Callerda, J. 1893 La region olfactoria del cerebro. N. Moya, Madrid.

Caosiy, E. C. 1917 The forebrain of Alligator mississippiensis. J. Comp. Neur., vol. 27, pp. 325-402.

Crosby, E. C., AND T. Humphrey 1939 Studies of the vertebrate telencephalon. The nuclear configuration of the olfactory and accessory olfactory formations and the nucleus olfactorius anterior of certain reptiles, birds and mammals. J. Comp. Neur., vol. 71 , pp. 121-213.

1941 Studies of the vertebrate telencephalon. The nuclear pattern of the anterior olfactory nucleus, tuberculum olfactorium and the amygdaloid complex in adult man. J. Comp. Neur., vol. 74, pp. 309-352.

Fox, C. A. 1940 Certain basal telencephalic centers in the cat. J. Comp. Neur., vol. 72, pp. $1-62$,

VAN GEHUCHTEN, A., AND I. MARMN 1891 Le bulbe olfactif chez quelques mammiferes. La Cellule, T. 7, p. 203-237.

GURDJian, E. S. 1925 Olfactory connections in the albino rat with special reference to the stria medullaris and anterior commissure. J. Comp. Neur., vol, 38, pp. 127-163. 1927 The diencephalon of the albino rat. J. Comp. Neur., vol. 43, pp. 1-114.

Herrick, C. J. 1910 The morphology of the forebrain in Amphibia and Reptilia. J. Comp. Neur., vol. 20, pp. 413-547.

1924 The nucleus olfactorius anterior of the opossum. J. Comp. Neur., vol. 37, pp. 317-359.

1933 The amphibian forebrain. VI. Necturus. J. Comp. Neur., vol. 58, pp. $1-288$

HINes, M. 1929 The development of the telencephalon in Sphenodon punctatum. J. Comp. Neur., vol. 35, pp. $483-537$.

Humphrey, T. 1936 The telencephalon of the bat. J. Comp. Neur., vol. 65, pp. 603-711. 1940 The development of the olfactory and the accessory olfactory formations in human embyos and fetuses. J. Comp. Neur., vol. 73, pp. 431-468.

HUmphret, T., and E. Crosby 1938 The human olfactory bulb. U. of M. Hosp. Bull., vol. 4 , pp. 61-62. 
JANSEN, J. 1930 The brain of Myxine glutinosa. J. Comp. Neur., vol. 49, pp. 359-507.

Johnston, J. B. 1915 The cell masses in the forebrain of the turtle, Cistudo carolina. J. Comp. Neur., vol. 25, pp. 393-468.

$1923 a$ Further contributions to the study of the evolution of the forebrain. Survey of forebrain morphology. J. Comp. Neur, vol. 36, pp. 143-192.

$1923 \mathrm{~b}$ Further contributions to the study of the evolution of the forebrain. J. Comp. Neur., vol. 35, pp. 337-481.

KLASS, M. 1929 A note on the olfactory striae in man. J. Comp. Neur., vol. 47, pp. 171-188. LAUER, E. W. 1945 The nuclear pattern and fiber connections of certain basal telencephalic centers in the macaque. J. Comp. Neur., vol. 82, pp. 215-254.

Loo, YU TAo 1931 The forebrain of the opossum, Didelphis virginiana. II. Histology. J. Comp. Neur., vol. 52, pp, 1-148.

Marburg, $O .1944$ The structure and fiber connections of the human habenula. J. Comp. Neur., vol. 80, pp. 211-233.

McCotrer, R. E. 1912 The connection of the vomero-nasal nerves with the accessory olfactory bulb in the opossum and other mammals. Anat. Rec., vol. 6, pp. 299-318.

Obenchaln, J. B. 1925 The brains of the South American marsupials Caenolestes and Orolestes. Field Museum of Natural History Publications, Zool. Ser., vol. 14, pp. 175-232.

RaMón y CAJaL 1911 Histologie du système nerveux, de l'homme et des vertébrés. Maloine, Paris.

Shesdon, R. E. 1912 The olfactory tracts and centers in teleosts. J. Comp. Neur., vol, 22, pp. $177-340$.

SMITH, O. C. 1930 The corpus striatum, amygdala and stria terminalis of Tamandua tetradactyla. J. Comp. Neur., vol. 51, pp. 65-127.

SonN'Tag, C. F., AND H. H. WoollaRd 1925 A monograph of Oryeteropus afe. IT. Nervous system, sense-organs and hairs. Proc. Zool. Soc. London, Part 3, pp. 1185-1235.

VAN DER SPRENKEL See Berkelbach van der Sprenkel.

Winklar, C., AND A. PotTre 1911 An anatomical guide to experimental researehes on the rabbit's brain. W. Versluys, Amsterdam.

1914 An anatomical guide to experimental researches on the cat's brain. W. Versluys, Amsterdam.

Young, A. W. 1926 The comparative anatomy of the septum pellueidum. Psyehiat. en neurol. Bl., vol. 30, pp. 203-234.

Young, M. W. 1936 The nuelear pattern and fiber connections of the non-cortical centers of the telencephalon of the rabbit. J. Comp. Neur., vol. 65, pp. 295-401.

\section{ABBREVIATIONS}

\section{A. PREOP., preoptic area}

ANT. AMYG. A., anterior amygdaloid area ANT. CONT. HIP., anterior continuation of the hippocampus

BULB OLF. ACC., accessory olfactory bulb

CAP. IN'T., internal capsule

CAP. EXT., external capsule

CH. OP., optic chiasma

CLAUS., claustrum

COM. ANT, anterior commissure

COM. ANT. L. ANT., anterior limb of the anterior commissure

COM. ANT. L. TEMP., temporal limb of the anterior commissure
COM. ANT. NUC. TR. OLF. LAT. COMP., nucleus of the lateral olfactory tract component of anterior commissure

COM. ANT. P. INTERB, interbulbar component of the anterior commissure COM. HIP., hippocampal commissure CORP. CAL., corpus callosum CORP. MAM., mammillary bodies CORP. MAM. COM, commissure below mammillary bodies

CORT. FRON., frontal cortex

CORT. INS., island cortex

CORT. PYR., piriform cortex 
D. B. B. AND NUC, diagonal band of Broca and nucleus

F. ENDORHIN., cndorhinal fissure

F. RHTN., rhinal fissure

FIL. OLF., olfactory fila

FIL. VOM., vomeronasal fila

FIM., fimbria

FOR., fornix

FOR. PRECOM., precommissural fornix

FOR. POSTCOM., posteommissural fornix

GL. PAL., globus pallidus

GR. PERIVEN'T., periventricular gray

GR. PERIVENT. PREOP., preoptic periventricular gray

HTP., hippocampus

HYPOTHAL., hypothalamus

ISL. CAL., island of Calleja

ISL. CAL. M., large medial island of Calleja

L. GLOM., glomerular layer

L. GRAN. EXT., external granular layer

L. GRAN. INT., internal granular layer

L. MIT. C., mitral cell layer

L. MOL. EXT., external molecular layer

L. MOL. INT., internal molecular layer

L. OUTW. MIT. C., outwandering mitral cell layer

M. F. B., medial forebrain bundle

M. INTER., intercalate mass

NUC. ACC., nucleus accumbens

NUC. AMYG. RAS., basal amygdaloid nucleus

NUC. AMYG. BAS. ACC., accessory basal amygdaloid nucleus

NUC. AMYG. BAS. P. MED., medial part of basal amygdaloid nucleus

NUC. AMYG. BAS. P. LAT, lateral part of basal amygdaloid nueleus

NUC. AMYG. CENT., central amygdaloid nucleus

NUC. AMYG. CENT. P. LAT., lateral part of central amygdaloid nucleus

NUC. AMYG. CENT. P. MED., medial part of central amygdaloid nucleus

NUC. AMYG. CORT., cortical amygdaloid nucleus

NUC. AMYG. LAT., lateral amygdaloid nucleus

NUC. AMYG. LAT. P. DOR., dorsal part of lateral amygdaloid nucleus

NUC. AMYG. LAT. P. VENT,, ventral part of lateral amygdaloid nucleus

NUC. AMYG. MED., medial amygdaloid nucleus
NUC. CAUD, caudate nucleus

NUC. COM. ANT. P. LAT., lateral part of nueleus of anterior commissure

NUC. COM. ANT. P. MED., medial part of nueleus of anterior commissure

NUC. D. B. B., nucleus of the diagonal band of Broca

NUC. OLF. ANT. P. DOR., anterior olfactory nucleus, pars dorsalis

NUC. OLF. ANT. P. EXT., anterior olfactóry nucleus, pars externa

NUC, OLF. ANT. P. LAT., anterior olfactory nucleus, pars lateralis

NUC. OLF. ANT. P. MED., anterior olfactory nucleus, pars medialis

NUC. OLF. ANT. P. POST., anterior olfactory nucleus, pars posterior

NUC. OLF. ANT, P. VENT., anterior olfaetory nucleus, pars ventralis

NUC. PREOP. LAT., lateral preoptic nueleus

NUC. PREOP. MED, medial preoptic nucleus

NUC. SEPT. HIP., septo-hippocampal nucleus

NUC. SEPT. LAT., lateral septal nucleus

NUC. SEPT. LAT. P. DOR., dorsal part of lateral septal nucleus

NUC. SEPT. LAT. P. VENT., ventral part of lateral septal nucleus

NUC. SEPT. MED., medial septal nucleus

NUC. SEPT. MED. P. DOR., dorsal part of medial septal nucleus

NUC. SEPT. MED. P. VENT., ventral part of medial septal nucleus

NUC. SUPRAOP., supraoptic nucleus

NUC. TRIANG. SEPT., nucleus triangularis septi

NUC. TR, OLF. LAT., nucleus of the lateral olfactory tract

PUT., putamen

ST. MED., stria medullaris

ST. TERM., stria terminalis

SUB. INOM., substantia innominata

TR. CORT. HAB. LAT., lateral cortico-habenular tract

TR. MAM. THAL., mammillo-thalamic tract

TR. OLF. INTER., intermediate olfactory tract

TR. OLF. LAT, lateral olfactory tract

TR. OLF. LAT. P. DOR., dorsal part of lateral olfactory tract

TR. OLF. LAT. P. VENT., ventral part of lateral olfactory tract

TR. OLF. MED., medial olfactory tract

TR. OP., optic tract 
TR. SEPT. CORT., septo-cortical tract TR. SEPT. HAB., septo-habenular tract TR. SEPT. TUB. AND TUB. SEPT., septotubereular and tuberculo-septal tracts TUB. OLF., olfactory tuberele

TUB. OLF. L. PLEX., plexiform layer of olfactory tubercle

TUB. OLF. L. POLY., polymorph layer of olfactory tubercle
TUB. OLF. L. PYR., pyramidal layer of olfactory tuberele

V. LA'T., lateral ventricle

V. OLF., olfactory ventricle

$\mathrm{T}$, intertubereular component of hippocampal commissure

$X$, fibers from stria terminalis to stria medullaris 


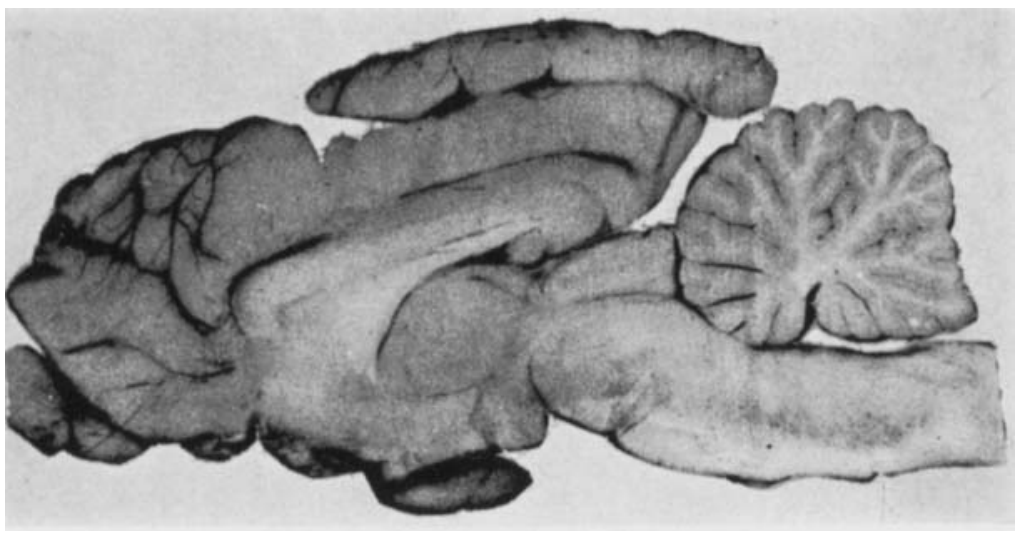

PLATES 1 TO 12

\section{FXPLANATION OF FIGURES}

Figure 1 is a photograph of a midsagittal section of the brain of the mink. The photograph is approximately three times the natural size.

Figures 2 to 14 (inclusive) are photomicrographs of transverse sections through the telencephalon of the mink (Mustela vison). These are stained with toluidin blue to show the nuclear pattern of the region. They are arranged in a rostrocaudal series, beginning with a plane through the olfactory bulb and extending to a plane through the eaudal end of the hemisphere. Figures 8 and 9 are shown at a magnification of 40 , the rest of the series are at a magnification of 20.

Figures 15 to 23 are photomicrographs of transverse sections of the brain of the mink, stained by the Weigert technique to show the fiber paths associated with the various telencephalie regions. They are arranged in a rostocaudal series beginning with a plane through the olfactory bulb and terminating at hypothalamic levels. A magnification of 20 was used for these illustrations. 


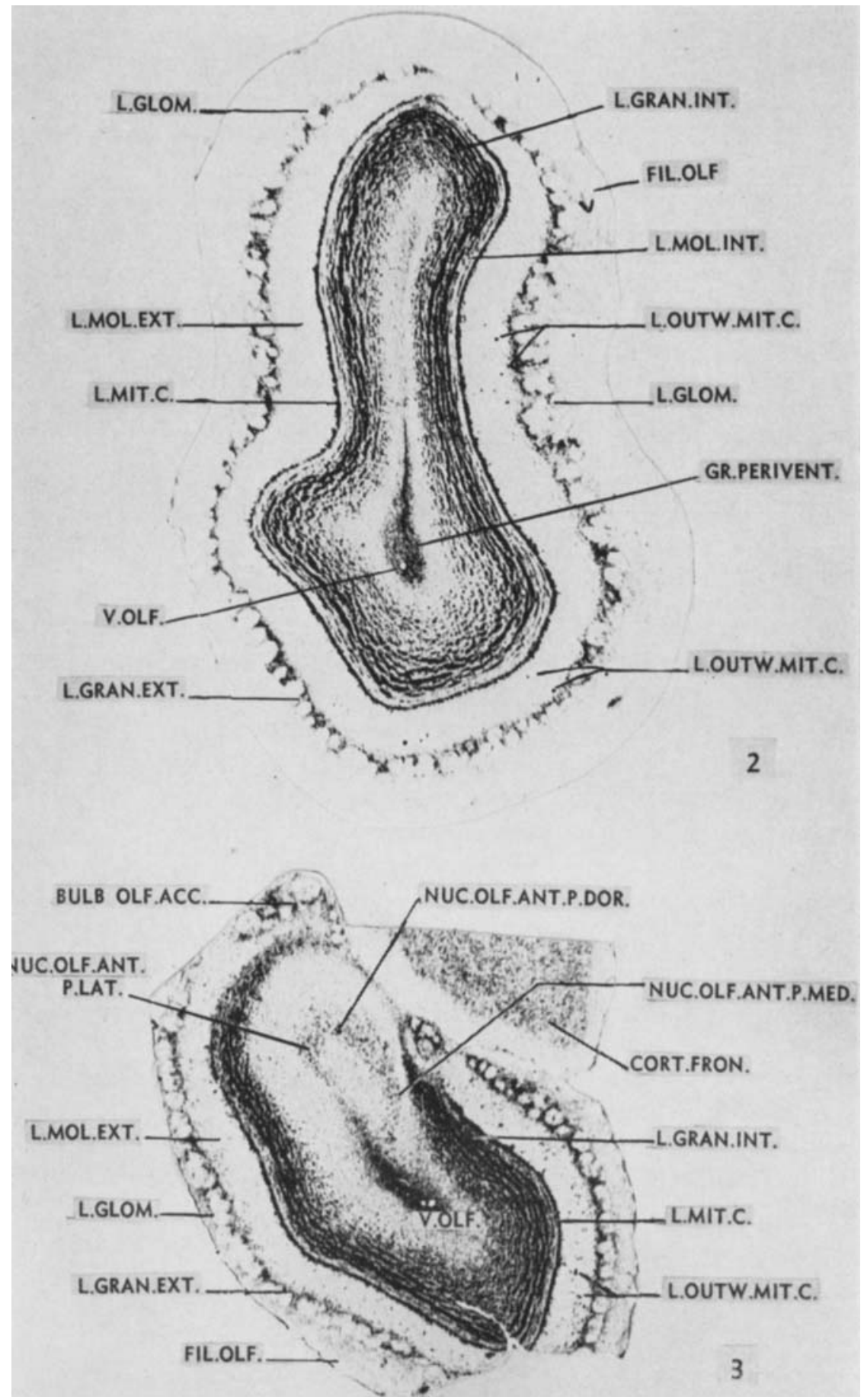




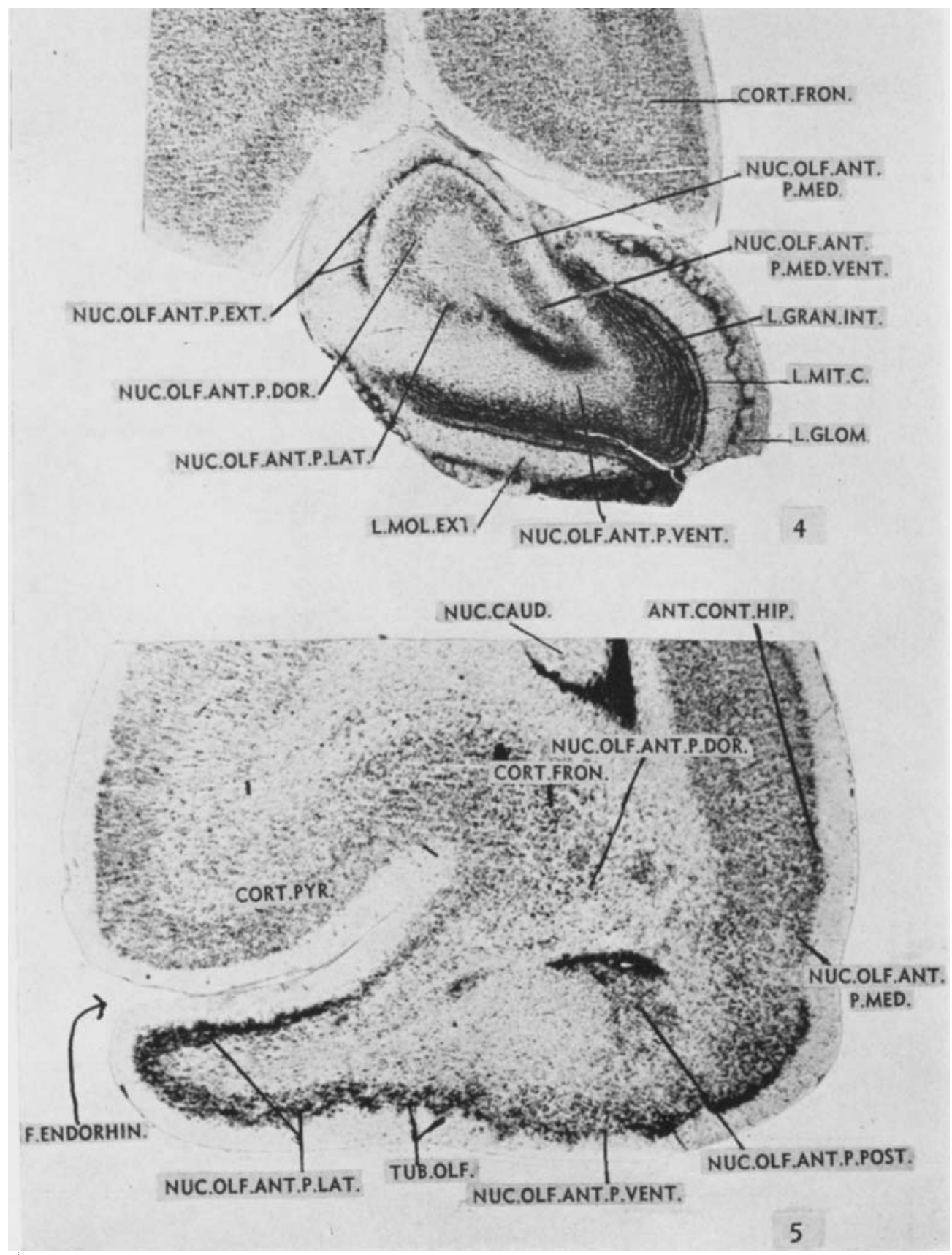




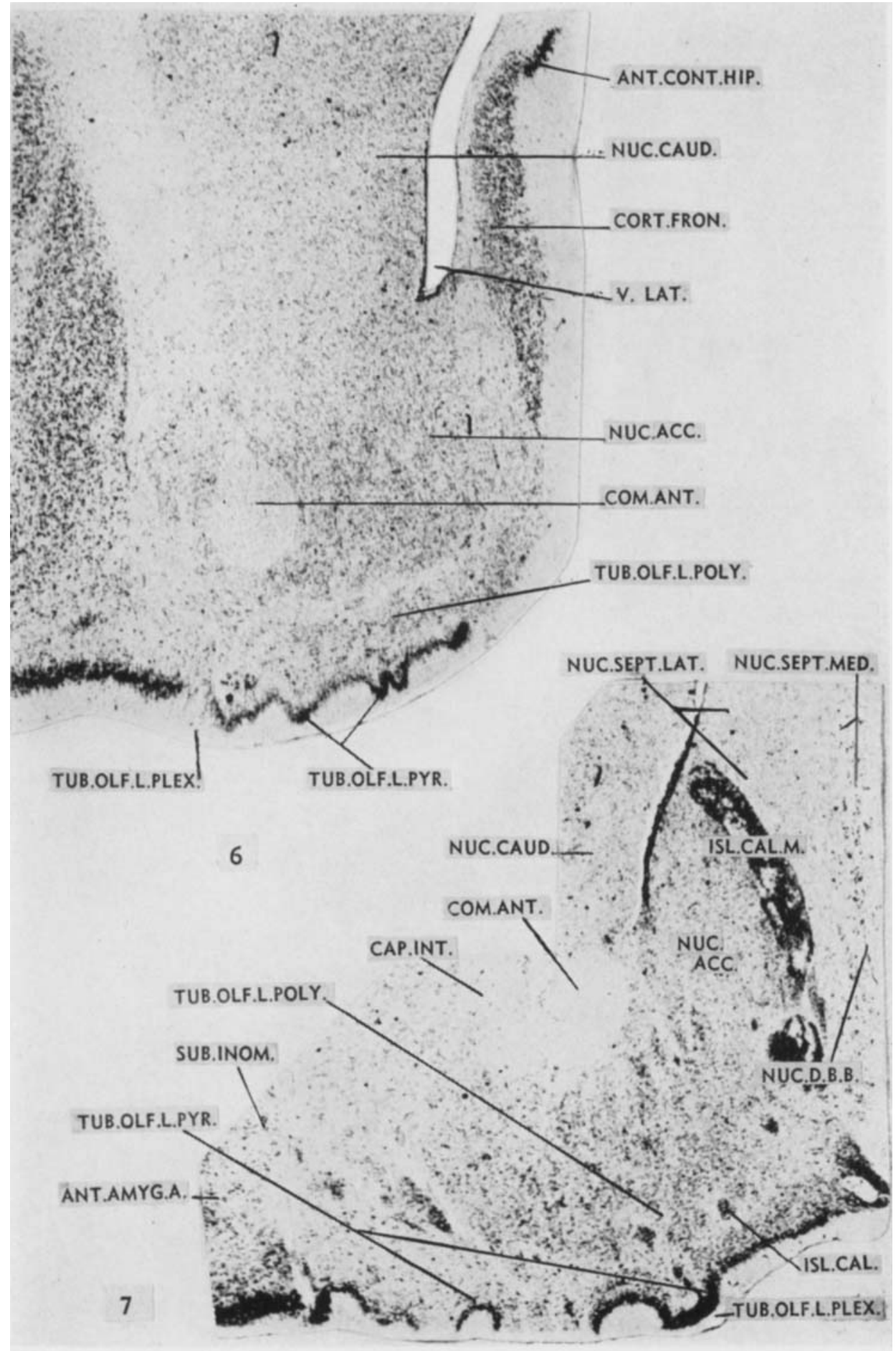




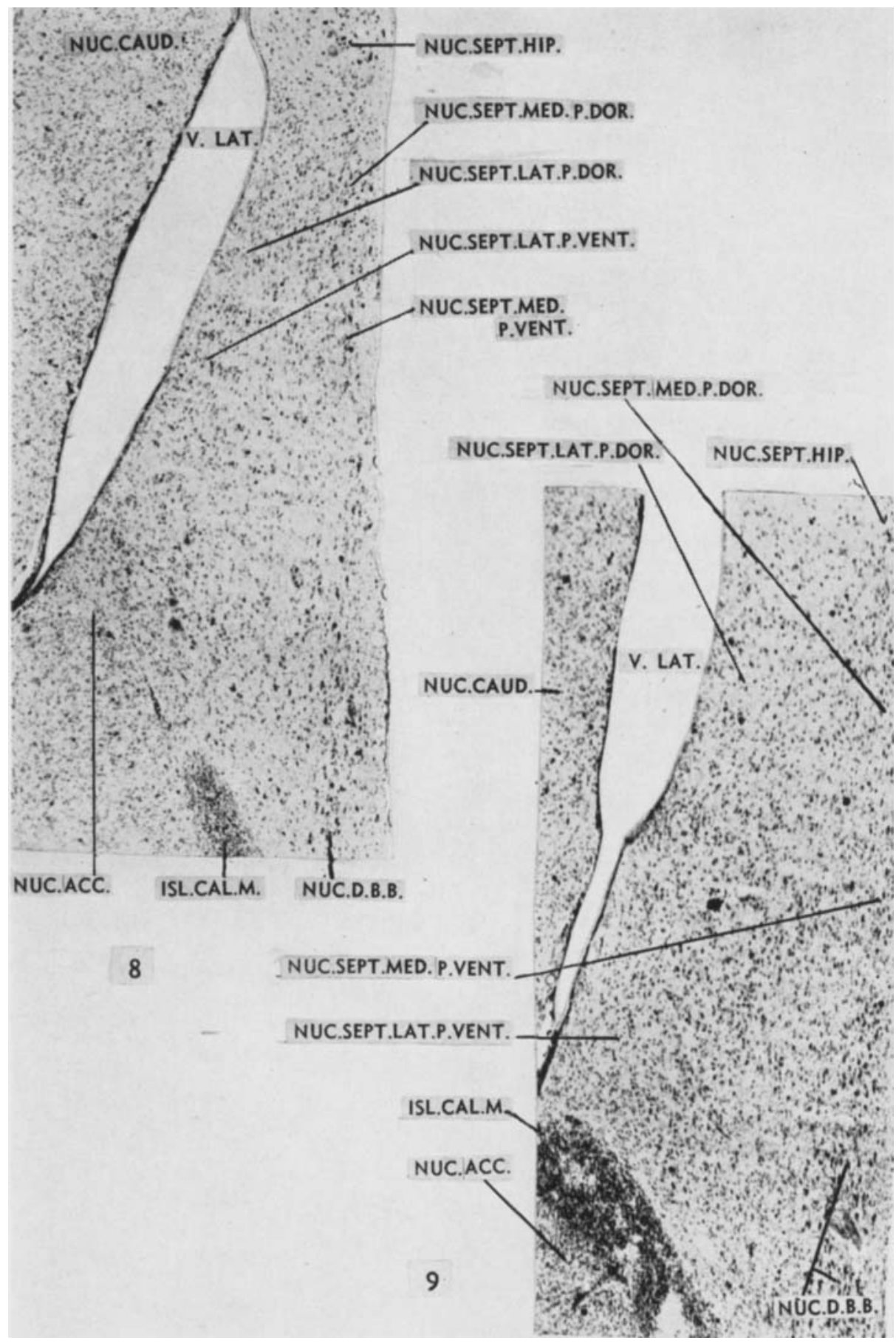


TELENCEPHALON OH THE MINK
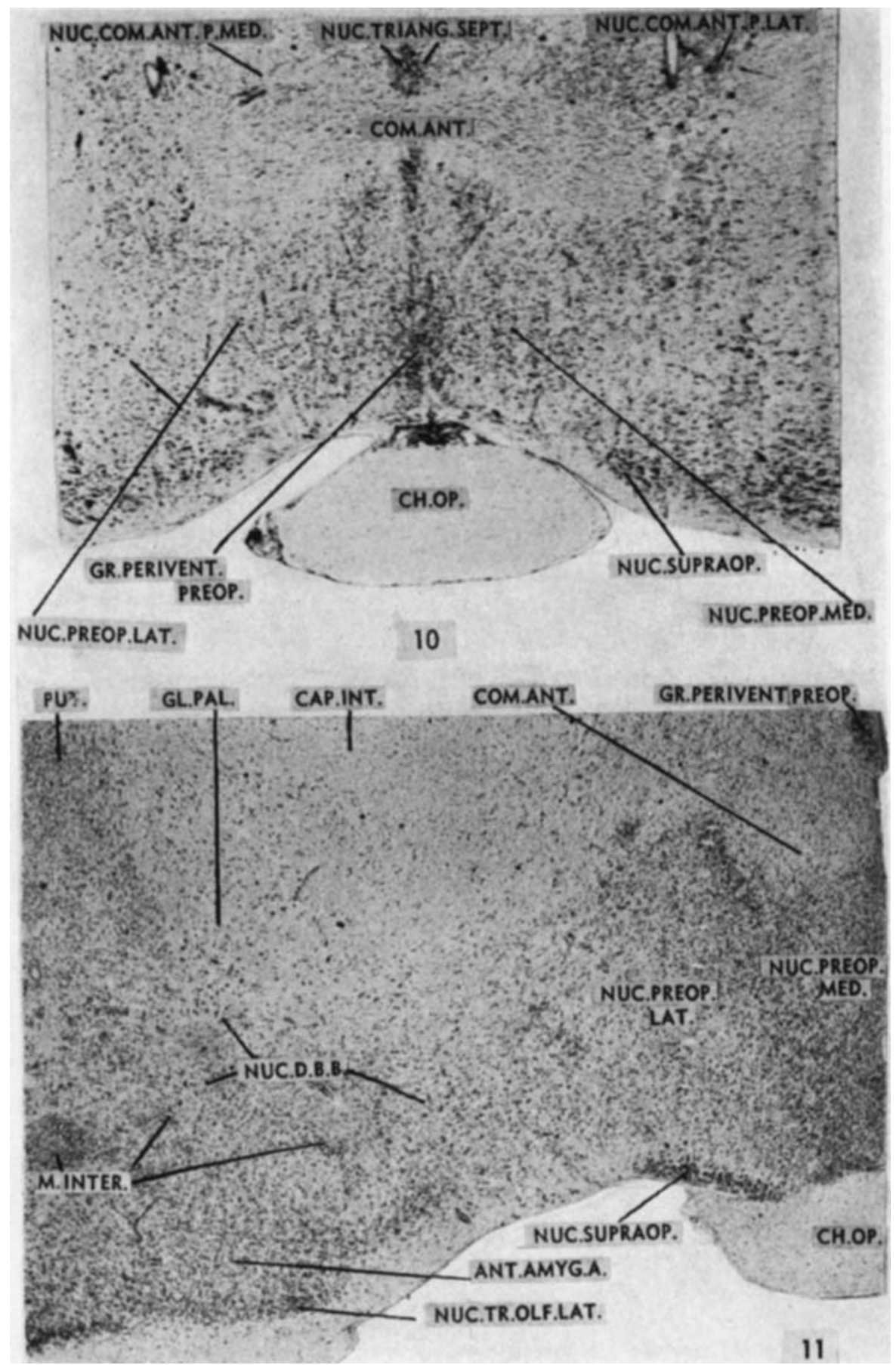
TELEXCEPHALON GE THE MINK

PLATE 7

MARGCERTTE WATSON JFSERICH

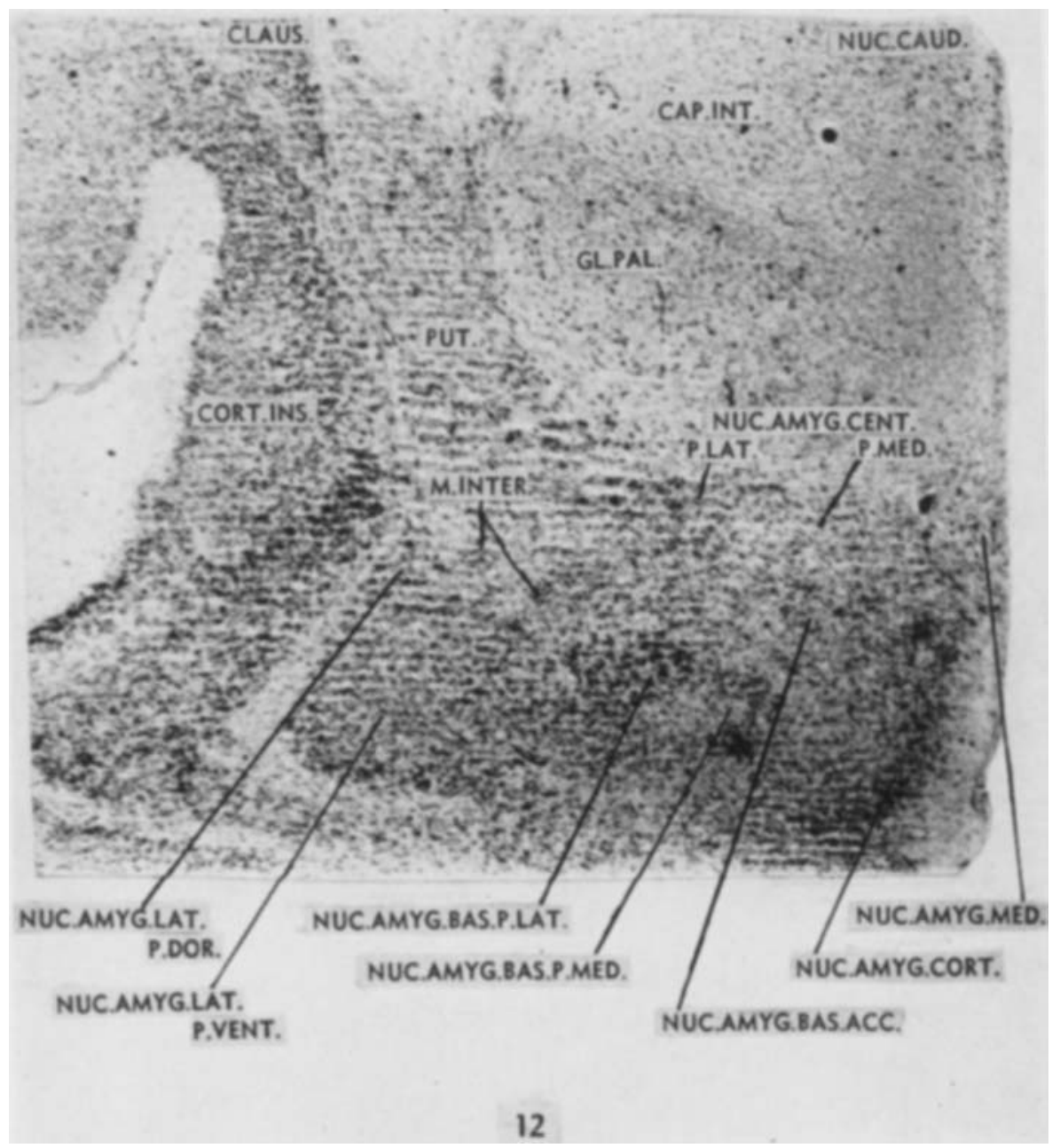


TELENCEPHALON OF THE MINK

PLATE 8

MARGUERITE WAT'SON JESERICH

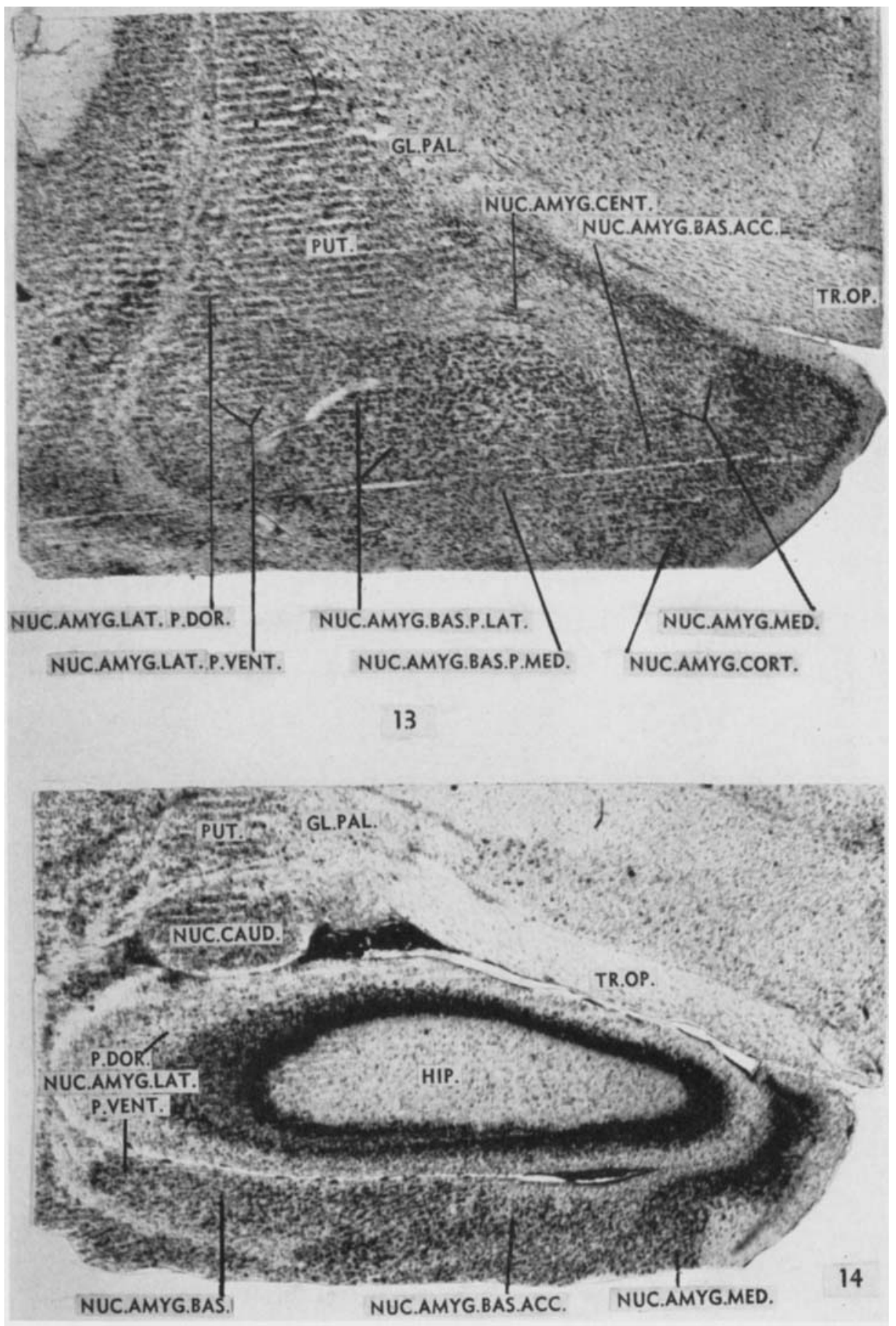


TELENCEPHALON OF THE MINK

MARGUERITE WATSON JESERICH
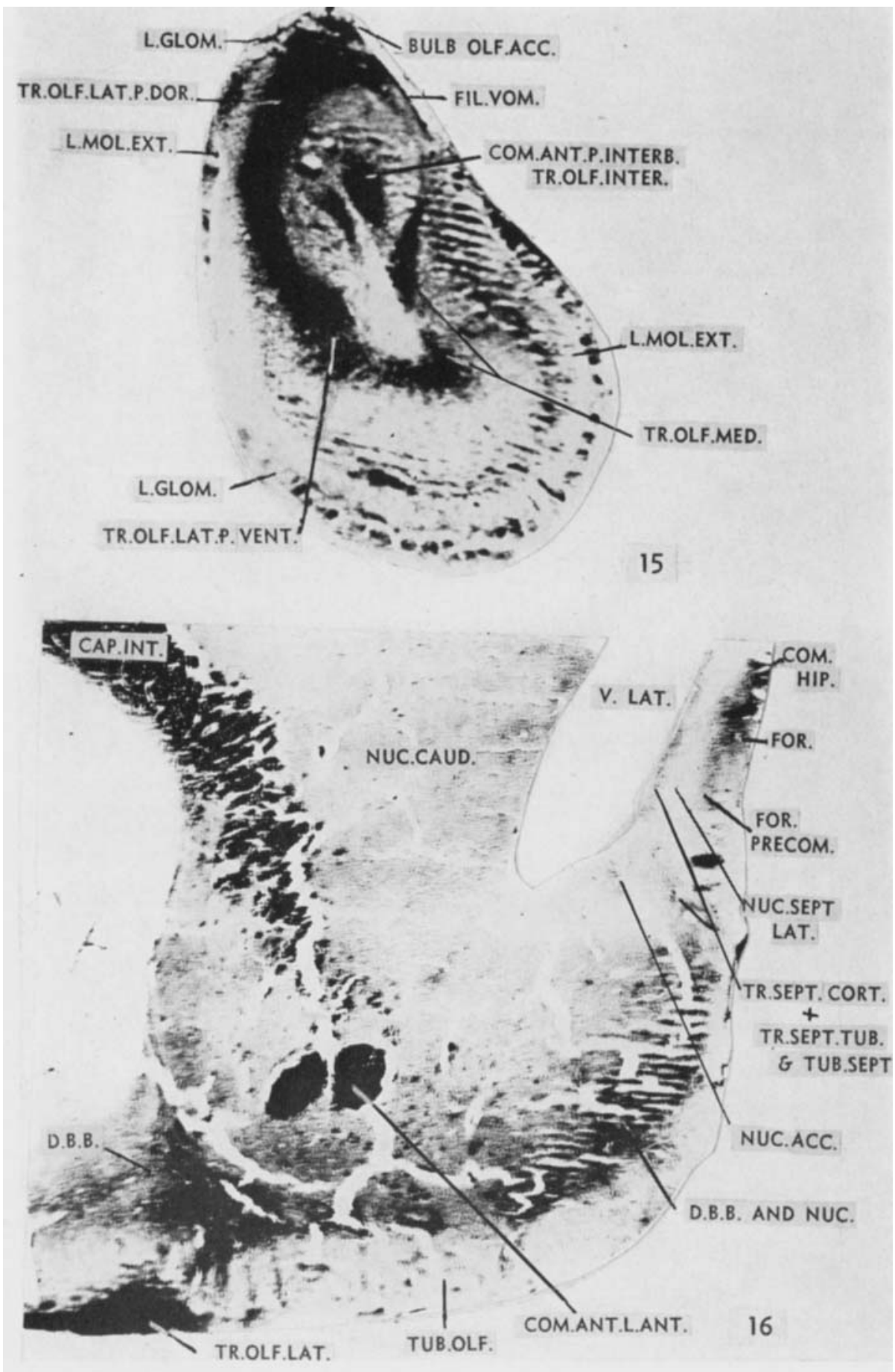


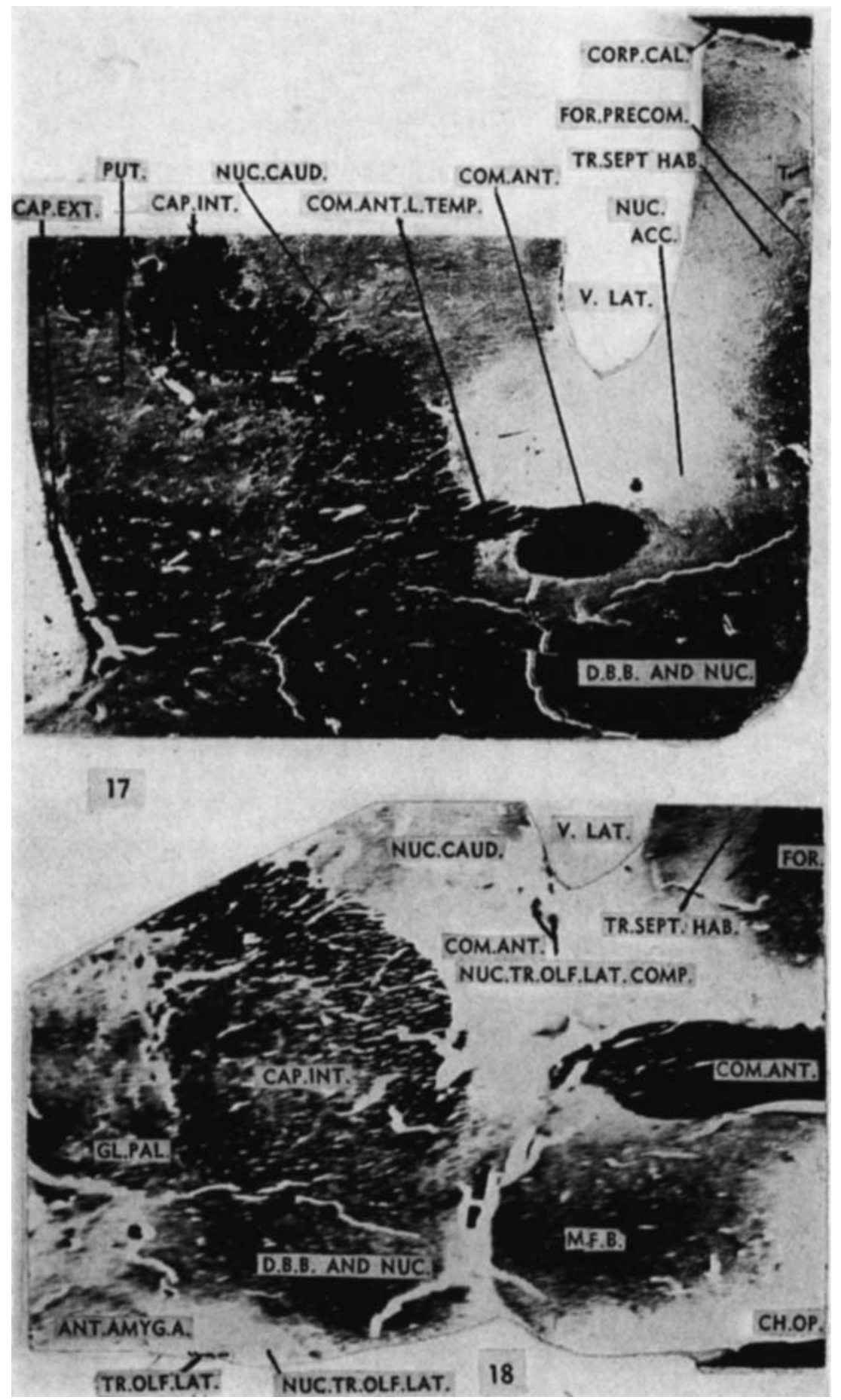




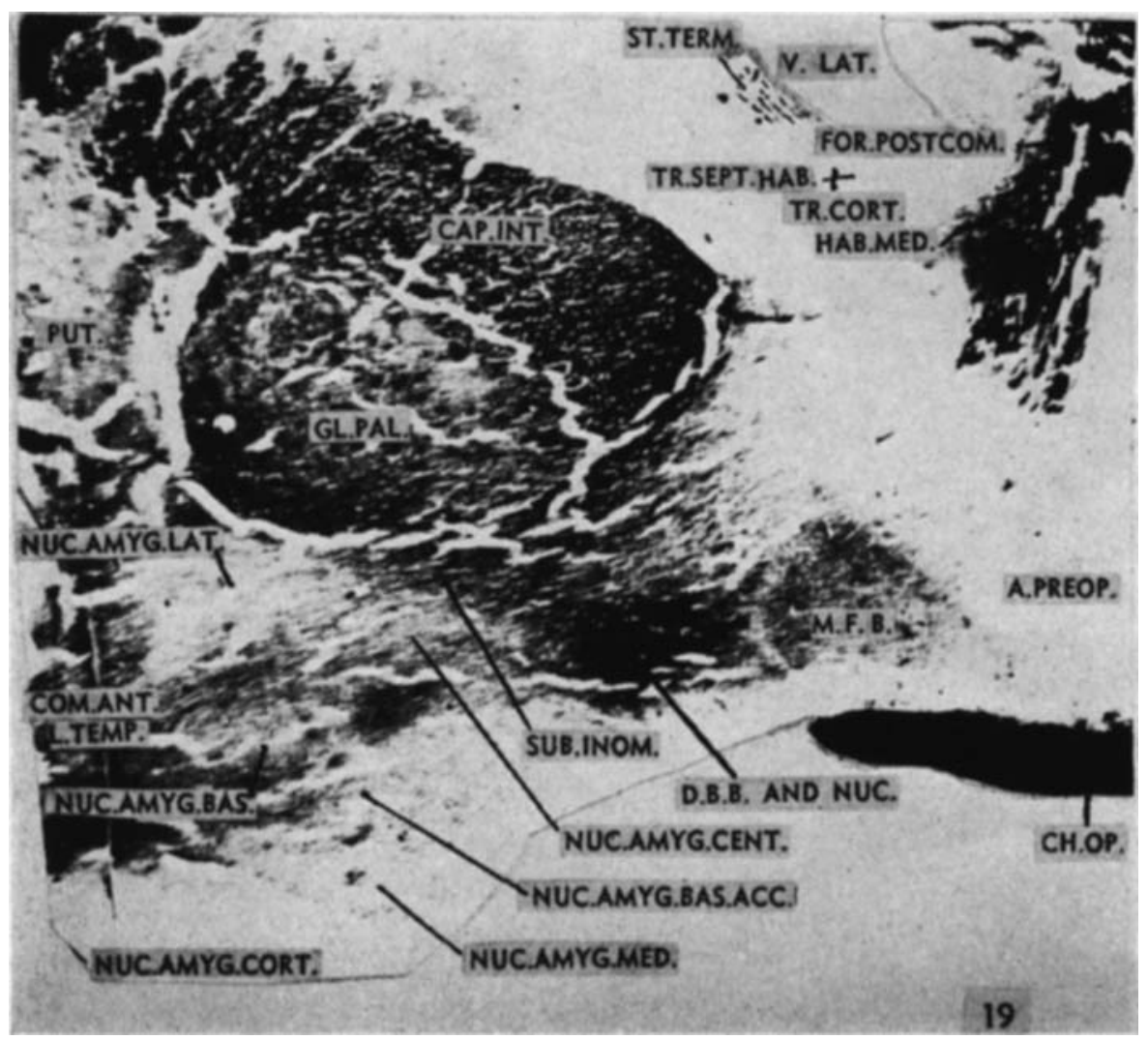




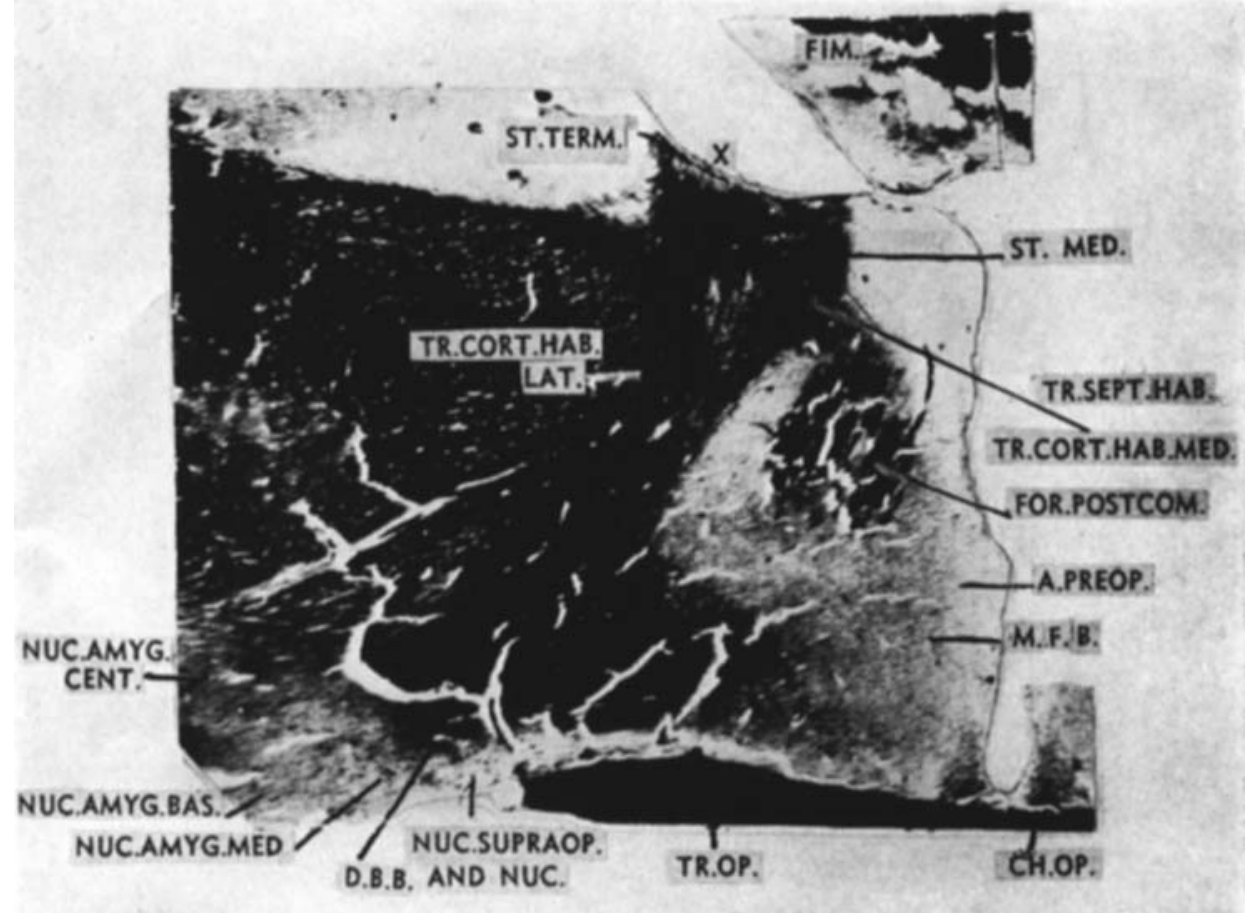

20

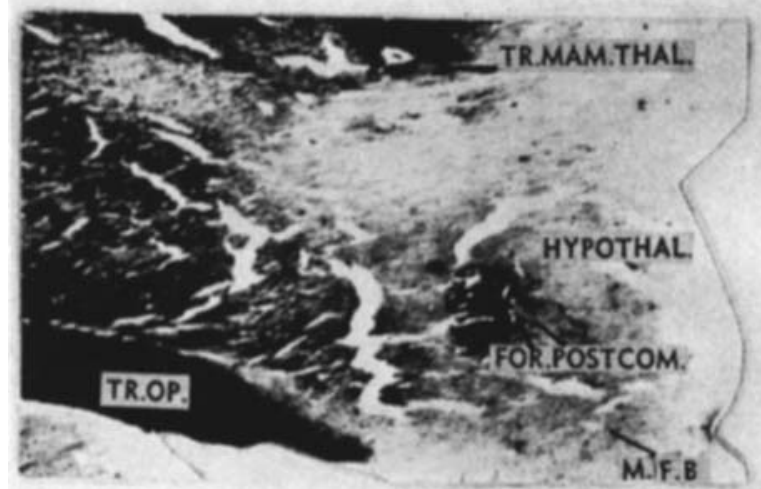

21
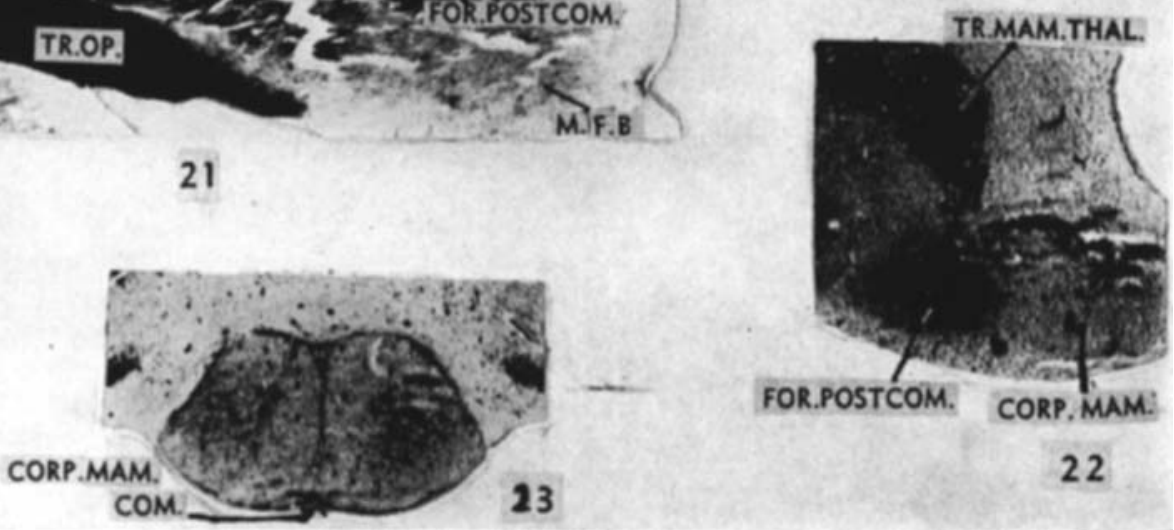